\title{
Osteogenic Protein-1 (Bone Morphogenetic Protein-7) Reduces Severity of Injury After Ischemic Acute Renal Failure in Rat
}

\author{
Slobodan Vukicevic, ${ }^{*}$ Vanja Basic, ${ }^{*}$ Dunja Rogic, ${ }^{\ddagger}$ Nikolina Basic, ${ }^{\star}$ Mei-Shu Shih, ${ }^{\S}$ Alyssa Shepard, ${ }^{\S}$ Don Jin, ${ }^{\S}$ \\ Bosukonda Dattatreyamurty,§ William Jones, ${ }^{\S}$ Haimanti Dorai, $\$$ Susan Ryan,,$\$$ Denise Griffiths, ${ }^{\S}$ James Maliakal,\$ \\ Mislav Jelic, ${ }^{\star}$ Maria Pastorcic, ${ }^{\star}$ Ana Stavljenic, ${ }^{\ddagger}$ and T. Kuber Sampath ${ }^{\S}$ \\ *Department of Anatomy, School of Medicine, University of Zagreb, Salata 11; Central Biochemical Laboratory, Clinical Hospital Rebro \\ Kispaticeva 12, 10000 Zagreb, Croatia; and ${ }^{\S}$ Creative BioMolecules, Inc., Hopkinton, Massachusetts 01748
}

\begin{abstract}
We have shown that osteogenic protein-1 (OP-1) (bone morphogenetic protein-7) is responsible for the induction of nephrogenic mesenchyme during embryonic kidney development. Gene knock-out studies showed that OP-1 null mutant mice die of renal failure within the first day of postnatal life. In the present study, we evaluated the effect of recombinant human OP-1 for the treatment of acute renal failure after $60 \mathrm{~min}$ bilateral renal artery occlusion in rats. Bioavailability studies in normal rats indicate that $\sim 1.4 \mu \mathrm{g}$ $\mathrm{OP}-1 / \mathrm{ml}$ is available in the circulation $1 \mathrm{~min}$ after intravenous administration of $250 \mu \mathrm{g} / \mathrm{kg}$, which then declines steadily with a half life of $30 \mathrm{~min}$. About $0.5 \%$ of the administered OP-1 dose/g tissue is targeted for OP-1 receptors in the kidney. We show that OP-1 preserves kidney function, as determined by reduced blood urea nitrogen and serum creatinine, and increased survival rate when administered $10 \mathrm{~min}$ before or 1 or $16 \mathrm{~h}$ after ischemia, and then at 24-h intervals up to $72 \mathrm{~h}$ after reperfusion. Histochemical and molecular analyses demonstrate that OP-1: (a) minimizes infarction and cell necrosis, and decreases the number of plugged tubules; ( $b$ ) suppresses inflammation by downregulating the expression of intercellular adhesive molecule, and prevents the accumulation and activity of neutrophils; (c) maintains the expression of the vascular smooth muscle cell phenotype in pericellular capillaries; and $(d)$ reduces programmed cell death during the recovery. Collectively, these data suggest that OP-1 prevents the loss of kidney function associated with ischemic injury and may provide a basis for the treatment of acute renal failure. (J. Clin. Invest. 1998. 102:202-214.) Key words: TGF- $\beta$ superfamily • kidney repair and regeneration - ischemia and reperfusion $\bullet$ cytoprotection - suppression of inflammation - maintenance of vascular smooth muscle cells
\end{abstract}

\section{Introduction}

Acute renal failure $(\mathrm{ARF})^{1}$ occurs as a result of a sudden decrease in renal blood flow, toxic, or obstructive insult to the re-

Address correspondence to T. Kuber Sampath, Creative BioMolecules, 45 South Street, Hopkinton, MA 01748. Phone: 508-782-1224; FAX: 508-782-1543; E-mail: ksampath@creativebio.com; or Slobodan Vukicevic. Phone: 385-1-4566-822; E-mail: slobodan.vukicevic@ zg.tel.hr

Received for publication 12 November 1997 and accepted in revised form 7 May 1998.

J. Clin. Invest.

(C) The American Society for Clinical Investigation, Inc. 0021-9738/98/07/0202/13 \$2.00

Volume 102, Number 1, July 1998, 202-214

http://www.jci.org nal tubule or inflammation and/or loss of vascular integrity in the tubulo interstitium or a rapid reduction in glomeruli function (1). The morbidity and mortality of established ARF remains unacceptably high (40-60\%) despite some advances in the management of the disease (2). Although it is not possible to reproduce all of the underlying pathophysiology in an animal model, bilateral renal ischemia and reperfusion injury in the rat has been used to evaluate the therapeutic potential of various agents for the prevention and treatment of ARF (3).

The ischemic insult begins with hypoperfusion and severe reduction in renal blood flow $(\mathrm{RBF})$ to nephrons leading to acute tubular necrosis, particularly in the $\mathrm{S}_{3}$ segment of proximal tubules $(4,5)$. In addition to qualifying the loss of renal function by serum and urine biochemical markers (creatinine, blood urea nitrogen [BUN], electrolyte and acid-base homeostasis), the ischemia followed by reperfusion is characterized by numerous morphological changes, varying with the nature and severity of the insult $(6,7)$. These include: loss of epithelial brush border in the proximal tubule, loss of polarity, loss of cell-cell and cell-matrix contact, and then cell death as a result of necrosis and apoptosis $(3,8,9)$. Concurrently, an array of noxious metabolic rearrangements like altered calcium fluxes, formation of reactive oxygen species, adenine nucleotide depletion, and activation of enzymes such as phospholipases and proteases perpetuate the ischemic/reperfusion injury, resulting in tubular sloughing and obstruction, thus contributing to the reduction in the GFR $(1,3)$. The ischemic injury is also accompanied by inflammatory and cytotoxic injury activated during reperfusion. Elaboration of inflammatory cytokine production (IL-1, TNF- $\alpha$, IL-6, IL-8, etc.) and enhanced expression and production of cell adhesion molecules (e.g., intercellular adhesive molecule [ICAM]-1) (10) allows neutrophils to adhere and accumulate in the vasa recta of the outer medulla causing capillary plugging and congestion (11-13). In addition, the sublethal ischemic injury affects vascular integrity via altered permeability, compression and congestion of peritubular capillaries, and vacuolization of smooth muscle cells (SMC), leading to increased renal vascular resistance and reduction in $\mathrm{RBF}$ (14).

The damaged kidney after ischemia and reperfusion has the capacity to completely restore its structure and function. Recovery from ischemic injury requires that damaged renal tubular cells regain polarity and reestablish cell-cell and cellextracellular matrix contact through cell migration, prolifera-

1. Abbreviations used in this paper: ARF, acute renal failure; BMP, bone morphogenetic protein; BUN, blood urea nitrogen; $\mathrm{Cr}$, creatinine; HGF, hepatocyte growth factor; ICAM, intercellular adhesive molecule; MPO, myeloperoxidase activity; OP, osteogenic protein; RBF, renal blood flow; RT, reverse transcriptase; SMA, smooth muscle $\alpha$-actin; SMC, smooth muscle cells. 
tion, and differentiation, thus reproducing certain aspects of renal ontogeny $(5,15)$. A variety of autocrine and paracrine peptide growth factors (EGF, HB-EGF, TGF- $\alpha$, TGF- $\beta$, IGF-1, and hepatocyte growth factor $[\mathrm{HGF}])$ have been shown to participate in the regulation of cell migration, growth and differentiation during repair, and regeneration of renal tubular epithelium after ischemia and reperfusion injury $(16,17)$. For example, EGF, when administered systemically within $2 \mathrm{~h}$ after reperfusion, significantly lowered BUN levels at all time points in rat ARF models (18). IGF-1 and HGF were shown to enhance the recovery of renal function and to prevent kidney damage $(19,20)$. An ideal therapy for ARF, in addition to a role in promoting cell growth and differentiation activity, should have a beneficial role in improving renal hemodynamic function, in reducing inflammation and in maintaining the vascular integrity.

Bone morphogenetic proteins (BMPs), also called osteogenic proteins (OPs), are members of the TGF- $\beta$ superfamily, originally identified by their ability to induce the formation of endochondral bone at extraskeletal sites (21, 22). Several $\mathrm{BMP} / \mathrm{OPs}$ are present at sites of epithelial-mesenchymal cell interaction during mammalian development and are responsible for cell migration, growth, and differentiation (23). OP-1 (BMP-7) is synthesized predominantly in the kidney during development (24) and induces metanephric differentiation of the permanent kidney (25). Gene knock-out experiments revealed that OP-1/BMP-7 null mutation mice die of renal failure within the first day of postnatal life $(26,27)$. The finding that OP-1 remains highly expressed in the postnatal kidney (28) and is present in the circulation, suggests that OP-1 may have a role in the repair and regeneration of the adult kidney.

In the present study, we examined the ability of systemically administered recombinant human OP-1 to modulate the degree of injury after ischemia and reperfusion in a rat ARF model. We present evidence that OP-1 reduces kidney dysfunction after injury, as measured by functional, histochemical, and molecular analyses.

\section{Methods}

Bioavailability studies. The bioavailability and clearance of OP-1 in serum upon systemic administration were determined using a sandwich OP-1 ELISA. Recombinant human mature OP-1 (29) was suspended in $20 \mathrm{mM}$ sodium acetate $(\mathrm{pH} 4.5)$ and administered to Sprague Dawley rats $(\sim 300 \mathrm{~g})$ at 125,250 , and $1,000 \mu \mathrm{g} / \mathrm{kg}$ through the tail vein in a volume of $500 \mu \mathrm{l}$. Blood was collected from the toes at 1, 3, $5,15,30$, and $60 \mathrm{~min}$ after the injection and serum was prepared for the determination of OP-1 levels.

The OP-1 ELISA uses two mouse monoclonal antibodies, each of which recognizes independent epitopes of the mature domain of OP-1. The capture antibody, 1B12 (30), was applied at $1.0 \mu \mathrm{g} / \mathrm{well}$ and the plates were blocked with $0.1 \mathrm{M}$ lysine, $10 \%$ goat serum in PBS. Each serum sample was diluted 1:10 with lysis buffer (0.05 M Tris, $\mathrm{pH} 8.0$, $0.15 \mathrm{M} \mathrm{NaCl}, 0.1 \%$ SDS, $1 \% \mathrm{NP}-40,0.5 \%$ DOC, $0.02 \% \mathrm{NaAzide})$. If further dilutions were required, the sample was diluted with $10 \%$ rat serum and $90 \%$ lysis buffer, such that the final rat serum concentration was always $10 \%$. For each diluted sample, $80 \mu \mathrm{l}$ was applied per well in triplicate. Purified mature OP-1 was used as a standard and was also diluted in $10 \%$ rat serum and $90 \%$ lysis buffer, after which $80 \mu \mathrm{l}$ were added per well (in triplicate). The secondary antibody, $12 \mathrm{G} 3$, which had been conjugated to alkaline phosphatase by glutaraldehyde cross-linking, was diluted with lysis buffer and $20 \mu \mathrm{l}$ were added to each well. The plates were incubated at $4^{\circ} \mathrm{C}$ overnight, and then washed with PBS, $0.1 \%$ Tween 20 . After washing $50 \mu \mathrm{l}$ of a luminescent substrate, Lumi-Phos 350 (Lumigen) was added to each well and the plate read on a luminometer (Dynatech Laboratories, Chantilly, VA). The arbitrary light unit, Lums, was plotted against the known concentration of the standards and a linear regression was used to fit a straight line to the points. From the equation resulting from the linear regression, the concentration of each sample was determined and corrections made for the dilutions used.

Biodistribution studies. The biodistribution of OP-1 to the kidney upon systemic administration was examined using ${ }^{125}$ I-labeled OP-1. Recombinant human mature OP-1 was radioiodinated to high or low specific activity by using a lactoperoxidase method (31). For high specific activity radiolabeling, $50 \mu \mathrm{g}$ of OP- 1 was iodinated with $3 \mathrm{mCi}$ of ${ }^{125}$ I to a specific activity of $49.99 \mu \mathrm{Ci} / \mu \mathrm{g}$ OP-1, and was used after mixing with unlabeled OP-1. Alternatively, $15.7 \mathrm{mg}$ of OP-1 was radiolabeled using $5 \mathrm{mCi}$ of ${ }^{125} \mathrm{I}$ to a specific activity of $0.24 \mu \mathrm{Ci} / \mu \mathrm{g}$ OP-1, and was used directly. OP-1 labeled to low and high specific activity was used at 250 or $1,000 \mu \mathrm{g} / \mathrm{kg}$. Rats were killed at $10 \mathrm{~min}$ or $3 \mathrm{~h}$ after administration of OP-1 through tail vein. The kidneys and liver were removed, fixed in $4 \%$ formaldehyde, fixed afterwards in $70 \%$ ethanol, and then counted using an autogama counter (Packard multiprias-1; Meriden, CT).

OP-1 binding studies. The specific cell surface binding of systemically administered OP-1 in the kidney was examined using a radioligand receptor assay. Plasma membranes were prepared from kidney cortex and medulla, essentially after a modified procedure of differential centrifugation in sucrose (31). Kidneys were collected from 10 2-mo-old Sprague Dawley rats and kept on ice. Cortex and medulla regions were dissected out and $2.5 \mathrm{~g}$ of each wet tissue were minced in $5 \mathrm{ml} 10.0 \mathrm{mM}$ Tris- $\mathrm{HCl}, \mathrm{pH} 7.2$ buffer, containing $1.0 \mathrm{mM} \mathrm{MgCl}_{2}, 1.0$ $\mu \mathrm{g} / \mathrm{ml}$ pepstatin A, $1.0 \mu \mathrm{g} / \mathrm{ml}$ leupeptin, $0.2 \mathrm{mM}$ PMSF, to which $15 \%$ sucrose was added. Tissue was homogenized at $4^{\circ} \mathrm{C}$ using a polytron homogenizer. The homogenate was diluted by adding $5 \mathrm{ml}$ buffer and homogenized again at the maximum setting for $1 \mathrm{~min}$. The homogenate was then centrifuged at $250 \mathrm{~g}$ for $15 \mathrm{~min}$ at $4^{\circ} \mathrm{C}$. The supernatant was diluted with buffer (without sucrose) to reduce sucrose concentration to $0.1 \mathrm{M}$. The diluted homogenate was centrifuged at $39,500 \mathrm{~g}$ for $60 \mathrm{~min}$ at $4^{\circ} \mathrm{C}$, and the pellet containing plasma membranes was saved. Plasma membranes were suspended in $50 \mathrm{mM}$ Hepes buffer, pH 7.4 containing $5 \mathrm{mM} \mathrm{MgCl}_{2}, 1 \mathrm{mM} \mathrm{CaCl}_{2}$, and $0.1 \mathrm{M}$ sucrose at a protein concentration of $11.5 \mathrm{mg} / \mathrm{ml}$, snap-frozen, and stored at $-70^{\circ} \mathrm{C}$ until analyzed.

The binding of radiolabeled OP-1 to isolated plasma membranes was performed as follows: $150 \mu \mathrm{l}$ of assay buffer $(50 \mathrm{mM}$ Hepes, $\mathrm{pH}$ 7.4 containing $10 \mathrm{mM} \mathrm{MgCl} 2,1 \mathrm{mM} \mathrm{CaCl}, 0.1 \mathrm{M}$ sucrose, and $1 \%$ BSA) or assay buffer containing increasing concentrations of unlabeled OP-1 ( $5 \mathrm{ng}-10.48 \mu \mathrm{g})$ was added to assay tubes. Approximately $300,000 \mathrm{cpm}\left(3 \mathrm{ng} / 50 \mu \mathrm{l}\right.$ of assay buffer) of ${ }^{125}$ I-labeled OP-1 and plasma membranes (200 $\mu \mathrm{g}$ protein in $200 \mu \mathrm{l}$ of $50 \mathrm{mM}$ Hepes buffer, $\mathrm{pH} 7.4$ containing $5 \mathrm{mM} \mathrm{MgCl}_{2}, 1 \mathrm{mM} \mathrm{CaCl}_{2}$ and $0.1 \mathrm{M}$ sucrose) were added to assay tubes and incubated for $22 \mathrm{~h}$ while rocking at $4^{\circ} \mathrm{C}$. After adding $400 \mu \mathrm{l}$ of Hepes buffer without sucrose, samples were mixed and centrifuged at $30,000 \mathrm{~g}$ for $45 \mathrm{~min}$ at $4^{\circ} \mathrm{C}$ to separate free radioligand from receptor-bound radioligand. Supernatant was aspirated and the pellet containing receptor-bound ${ }^{125}$ I-labeled OP-1 was suspended in $0.8 \mathrm{ml}$ Hepes buffer without sucrose. The tubes were then centrifuged for $45 \mathrm{~min}\left(4^{\circ} \mathrm{C}\right)$ at $30,000 \mathrm{~g}$. The supernatant was aspirated and the radioactivity of the pellet containing receptor-bound radioligand was counted in an autogamma counter. In parallel assays, ${ }^{125}$ I-labeled OP-1 binding to isolated plasma membranes was competed with increasing concentrations of unlabeled BMP-2, TGF- $\beta 1$, CDMP-1/GDF-5, EGF, IGF-1, bFGF, or PDGF.

Animal surgical procedures and experimental protocols. Wistar male rats of 200-250 g (Pliva Breeding Laboratory, Zagreb, Croatia) were fasted for $12 \mathrm{~h}$ before surgery. After intraperitoneal administration of ketamin $(20 \mathrm{mg} / \mathrm{kg})$ anesthetic, both renal arteries were dorsally occluded for $60 \mathrm{~min}$ with microaneurysm clamps (Roboz). Vehicle buffer or OP-1 containing $20 \mathrm{mM}$ sodium acetate buffer $(500 \mu \mathrm{l})$ 
were administered via the tail vein. All animals were subjected to intraperitoneal administration of $1-3 \mathrm{ml}$ of prewarmed $\left(37^{\circ} \mathrm{C}\right)$ saline $(0.9 \% \mathrm{NaCl})$ to compensate any fluid loss during the surgery. Experiments were blinded and rats were terminated at different time intervals ranging from $30 \mathrm{~min}$ to $18 \mathrm{~d}$. Blood samples $(0.5 \mathrm{ml})$ were obtained from the orbital plexus at $0,24,48$, and $72 \mathrm{~h}$ and, in some cases, at $30 \mathrm{~min} ; 2,8$, and $96 \mathrm{~h}$; and $18 \mathrm{~d}$ after reperfusion. For GFR measurements, urine was collected on metabolic cages for $24 \mathrm{~h}$ as previously described (32). Serum and urine creatinine was measured by a Jaffe method (33). BUN was measured by a glutamate dehydrogenase ultraviolet procedure, phosphorus by a molybdate method, and calcium by an o-cresolphtaleine method. Serum electrolytes were measured by indirect potentiometry. 15 independent experiments in a total of 456 rats were performed. For a prophylactic mode, OP-1 was given $10 \mathrm{~min}$ before surgery and then at 24,48 , and $72 \mathrm{~h}$ thereafter and for a therapeutic mode, the first OP-1 injection was given either at 1 or $16 \mathrm{~h}$, and then at $24 \mathrm{~h}$ intervals up to $96 \mathrm{~h}$ after reperfusion.

Histomorphometry and immunocytochemistry. Upon death, each kidney was split longitudinally and one half was fixed in $4 \%$ paraformaldehyde. Two consecutive sections from paraffin-embedded blocks were stained with $H \& E$ and PAS. The morphometric measurements were done on longitudinal sections using an eye-piece grid that contains 100-point grid lines under a Nicon microscope (Nikon Optiphot-2; MVI, Avon, MA). The grid was calibrated by a stage micrometer and the area of a specific feature was measured by counting the number of intersects (points or hits) that were superimposed on the tissue of interest. All counts were done through $1 \times$ objective lens. Each point or hit represents an area of $0.61 \mathrm{~mm}^{2}$. Verification of features were done at a higher magnification, if they could not be discerned through the $1 \times$ objective lens.

Morphometric variables include total tissue area, $\operatorname{TAr}\left(\mathrm{mm}^{2}\right)$; dilated tubular area, DTAr $\left(\mathrm{mm}^{2}\right)$; plugged tubular area, $\operatorname{PTAr}\left(\mathrm{mm}^{2}\right)$; infarcted area, $\operatorname{IAr}\left(\mathrm{mm}^{2}\right)$; and necrotic area, $\operatorname{NAr}\left(\mathrm{mm}^{2}\right)$. Dilated and plugged tubular area were also expressed as a percent of the total tissue area excluding the infarcted and necrotic areas, [\%DTAr/TAr $(\mathrm{IAr}+\mathrm{Nar})]$ and $[\% \mathrm{PTAr} / \mathrm{TAr}-(\mathrm{IAr}+\mathrm{NAr})]$. Infarcted and necrotic area were also expressed as a percent of the total tissue area (\%IAr/TAr and \%NAr/TAr). Dilated tubule was defined as a tubular structure having distended lumen and identifiable epithelial cells. Plugged tubule was defined as a tubular structure having debris-filled lumen and identifiable epithelial cells. Infarcted area was defined as a portion or a zone of the kidney, showing identifiable tissue profiles and lost cellular details that were stained bright pink by H\&E stain, and was associated with regional congestion in the outer medulla. Necrotic area was defined as a portion or a zone of the kidney other than the infarcted area, showing loss of both tissue profiles and cellular details.

Immunocytochemistry was performed using the immunoperoxidase detection system (Zymed, San Francisco, CA). The following monoclonal antibodies were used: PCNA (proliferating cell nuclear antigen; DAKO, Copenhagen, Denmark), smooth muscle $\alpha$-actin (SMA) (DAKO), smooth muscle myosin IgG (BTI, Stoughton, MA), and I-CAM (CD 54; DAKO). A minimum of 3,000 cells was counted per kidney section stained for PCNA and SMA, and the number of positive cells was expressed as a percentage of total counted cells in the subdivisions of cortex, and/or $\mathrm{S}_{3}$ zone.

Apoptotic cells were detected by a TACS 2 TdT in situ apoptosis system (Trevigen, Gaithersburg, MD). The total number of apoptotic cells was counted in cortex and medulla in three sections per kidney from eight independent animals per group, killed on day 1, 2, 3, and 5 after reperfusion.

Reverse transcriptase (RT)-PCR and in situ hybridization. RNA was isolated with TRIzol as indicated by manufacturer (GIBCO BRL, Gaithersburg, MD) from whole kidneys at several time points after reperfusion. Contaminating genomic DNA was removed with RNAse-free deoxyribonuclease after the protocol of the manufacturer (GIBCO BRL). Complementary DNA was synthesized with Superscript reverse transcriptase (GIBCO BRL). $4 \mu$ l of deoxyribo- nuclease-treated RNA were incubated with $2 \mu$ loligodT at $70^{\circ} \mathrm{C}$ for 10 min. $14 \mu \mathrm{l} 5 \times$ buffer, $7 \mu \mathrm{l}$ DTT $(0.1 \mathrm{M}), 3.5 \mu \mathrm{l}$ of each nucleotide $(10 \mathrm{mM}), 1.5 \mu \mathrm{l}$ RNAse inhibitor (Boehringer Mannheim, Indianapolis, IN), and $2 \mu \mathrm{l}$ Superscript reverse transcriptase (GIBCO BRL) were added to each reaction. Samples were incubated $10 \mathrm{~min}$ at room temperature, $50 \mathrm{~min}$ at $42^{\circ} \mathrm{C}, 10 \mathrm{~min}$ at $50^{\circ} \mathrm{C}$, and $5 \mathrm{~min}$ at $90^{\circ} \mathrm{C}$. RNAse $\mathrm{H}(1 \mu \mathrm{l})$ (GIBCO BRL) was added to the reactions, and samples were incubated for $20 \mathrm{~min}$ at $37^{\circ} \mathrm{C}$. PCR was performed as indicated by manufacturer (Perkin-Elmer, Norwalk, CT) with the following primers: OP-1 (5'-GCACCTCCAGGGAAAAC; 3 '-AAGCCCAGATGGTACGG), TGF- $\beta-1$ (5'-CTTCAGCTCCACAGAGAAGAACTGC; 3'-CACGATCATGTTGGACAACTGCTCC) EGF (5'-AAGCCACGGTTACATTCACTCC; 3'-GAGTACAGCCGTGATTCTGCAA),), IGF-1 (ATGAGCGCACCTCCAATAAAGA; 3'-ATATTTGGAAGGTGTTCCGATG), ICAM (5'-GGGAATCCAGCCCCTAATCTGA; 3'-GACTGTCCCAGCTTTCCCATGT), NCAM (5'-CGCAAAGCCCAAAATCACCTAT; 3'-TTGGAATGCCATGCTTCTTCAC), and GAPDH (5'-ACCACAGTCCATGCCATCAC; 3'-TCCACCACCCTGTTGCTGTA). Reactions included $5 \mu \mathrm{l} 10 \times$ buffer, $3 \mu \mathrm{l} \mathrm{MgCl} \mathrm{Mg}_{2}, 1 \mu \mathrm{l} \mathrm{dNTP}, 1 \mu \mathrm{l} 3^{\prime}$ primer, $1 \mu \mathrm{l} 5^{\prime}$ primer, $0.5 \mu \mathrm{l}$ Taq polymerase (Perkin-Elmer) and $1 \mu \mathrm{l}$ cDNA. Samples were incubated for $5 \mathrm{~min}$ at $94^{\circ} \mathrm{C}$, followed by 32 cycles of $45 \mathrm{~s}$ at $94^{\circ} \mathrm{C}, 45 \mathrm{~s}$ at $58^{\circ} \mathrm{C}, 1 \mathrm{~min}$ at $72^{\circ} \mathrm{C}$, and final extension at $72^{\circ} \mathrm{C}$ for 10 min in a Perkin-Elmer DNA Thermal Cycler. To compare the relative quality of the RT-PCR reactions, the transcription level of GAPDH, a "housekeeping" gene was used as a control. GAPDH gene expression was found to be similar at all the time points examined, enabling analysis of the relative levels of gene expression for the desired genes (34). Reactions without cDNA were used as a negative control. Rat placental (E17) and rat embryonal (E15) cDNA were used as positive controls. Reactions were repeated at least twice.

OP-1 mRNA distribution was analyzed on kidney sections of sham, vehicle-, and OP-1-treated rats using specific OP-1 RNA sense and antisense probes. Probes were generated from a fragment of rat OP-1 in the prodomain cloned into PGEM-3Z in both directions. The plasmids pS 630/pS 631 were cut with HindIII and labeled RNA synthesized of the T7 promoter using a Novagen labeling kit (Madison, WI). In situ hybridization was performed as previously described $(24,25)$.

Neutrophil accumulation and activity. The neutrophil infiltration was determined using naphthol AS-D chloroacetate esterase staining (Sigma Chemical Co., St. Louis, MO) on histologic sections. The neutrophils were counted in the cortex and $\mathrm{S}_{3}$ zone (outer medulla and inner cortex) using an ocular-grid. Data were expressed as number of neutrophils per $\mathrm{mm}^{2}$, evaluated on 100 high power fields per section, two sections per animal from eight independent rats at $24 \mathrm{~h}$ after injury. In addition, neutrophil activity was determined at $24 \mathrm{~h}$ after injury by myeloperoxidase activity (MPO). For MPO, kidneys were extracted in $0.5 \%$ HTAB (Sigma Chemical Co.) in $50 \mathrm{mM} \mathrm{KPO}_{4}$ buffer, $\mathrm{pH}$ 6.0, homogenized for $10 \mathrm{~min}$, sonicated for $5 \mathrm{~min}$, and finally the lysate was centrifuged for $60 \mathrm{~min}$ at $20,000 \mathrm{~g} .10 \mu \mathrm{l}$ of extract was incubated with $1 \mathrm{ml}$ of $50 \mathrm{mM} \mathrm{KPO}_{4}$ buffer containing $0.167 \mathrm{mg} / \mathrm{ml}$ 0-dianisidine (Sigma Chemical Co.) and $0.0005 \% \mathrm{H}_{2} \mathrm{O}_{2}$ at $25^{\circ} \mathrm{C}$. Absorbance was determined at $460 \mathrm{~nm}$ using a myeloperoxidase standard (Oxis), and normalized to kidney wet weight.

Statistical analysis. Two-way analysis of variance and post hoc analysis with Duncan's multiple range test were performed to determine the effects of treatment and time on biochemical and histological parameters. Mann-Whitney-U test and Chi-square test were used to determine the significance of differences in results between selected groups.

\section{Results}

Bioavailability studies. Fig. $1, A-C$ shows the availability of OP-1 in the circulation, its distribution, and specific cell surface binding in the kidney of normal growing rats (250-300 g). 

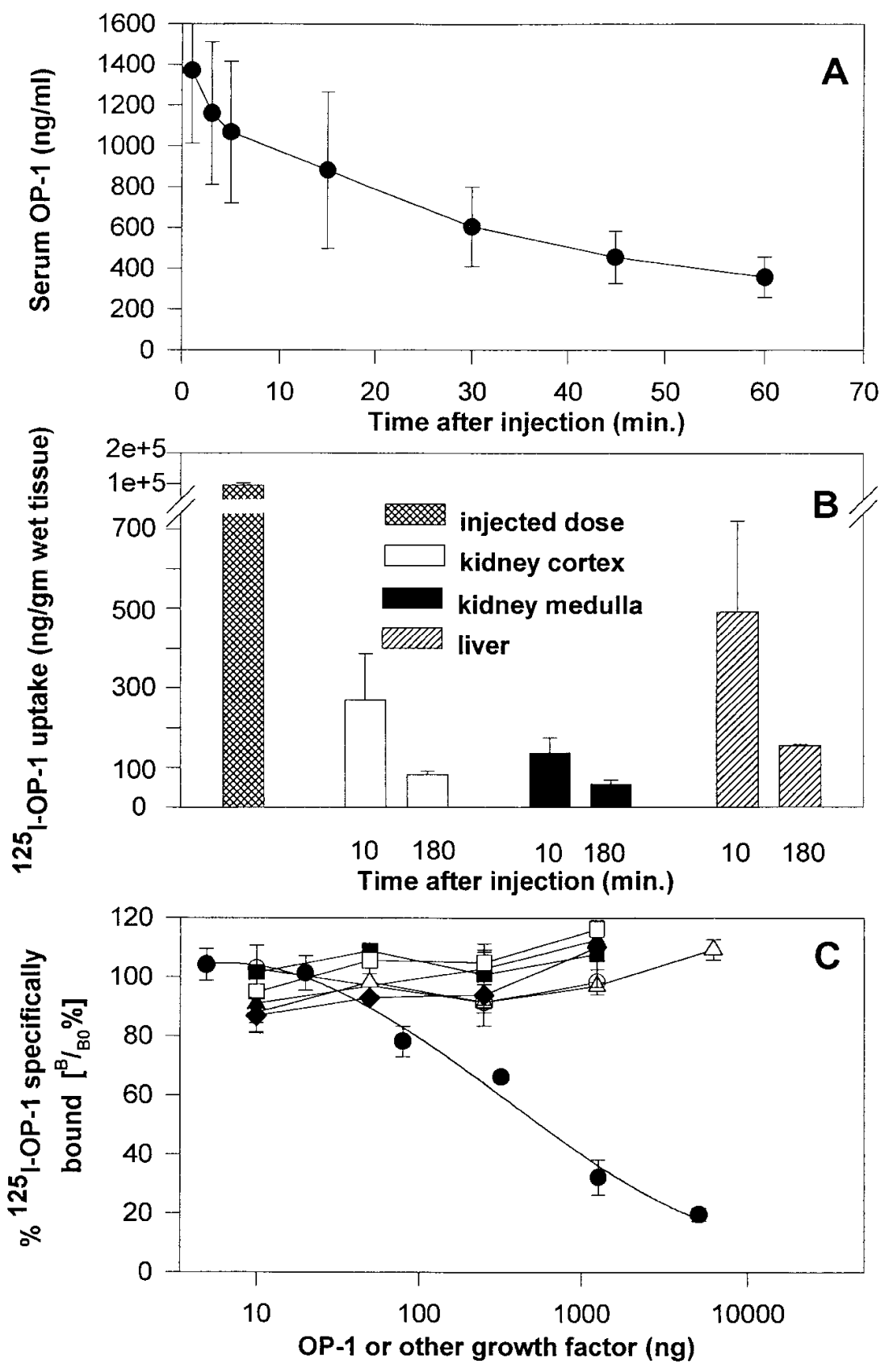

Figure 1. Pharmacokinetic properties of OP-1. $(A)$ Bioavailability of OP-1 in rat serum after systemic administration of mature OP-1 $(250 \mu \mathrm{g} / \mathrm{kg}$ bw). (B) Biodistribution of ${ }^{125}$ I-labeled OP-1 in rat kidney and liver. Rats received single tail vein injection of ${ }^{125}$ I-labeled OP-1 (specific activity 0.237 $\mu \mathrm{Ci} / \mu \mathrm{g}$ ) at dose level of $250 \mu \mathrm{g} / \mathrm{kg}$, and were killed at 10 or $180 \mathrm{~min}$ after injection. Kidneys were dissected to separate cortex and medulla regions. The relative uptake of ${ }^{125}$ I-labeled OP-1 by tissues was expressed as ng of radiolabeled OP- $1 / \mathrm{g}$ wet tissue weight. $(C)$ Effect of unlabeled OP-1 or other growth factors on specific binding of ${ }^{125} \mathrm{I}$ labeled OP-1 to receptor-enriched kidney cortex plasma membranes. Plasma membranes were incubated with $300,000 \mathrm{cpm}(\sim 3 \mathrm{ng})$ of ${ }^{125}$ I-labeled OP-1 in the presence or absence of increasing concentrations of unlabeled OP-1 (๑), PDGF $(O)$, TGF- $\beta(\boldsymbol{\Delta}), \operatorname{IGF}(\triangle)$, FGF $(\square)$, CDMP-1 (ロ), or BMP-2 $(\bullet)$ for $20 \mathrm{~h}$ at $4^{\circ} \mathrm{C}$. Values $\left({ }^{B}{ }_{B O} \%\right)$ are expressed as percent of specific binding determined in absence of unlabeled OP-1 or other growth factor. Each point is average \pm SD of triplicate determinations.

Table I. Effect of OP-1 on Serum Electrolytes (mEq/liter) in Rats After Renal Ischemia

\begin{tabular}{|c|c|c|c|c|c|c|c|c|c|c|}
\hline \multirow[t]{2}{*}{ Day } & \multicolumn{2}{|c|}{ Calcium } & \multicolumn{2}{|c|}{ Phosphorus } & \multicolumn{2}{|c|}{ Potassium } & \multicolumn{2}{|c|}{ Sodium } & \multicolumn{2}{|c|}{ Chloride } \\
\hline & V & $O P-1$ & V & $O P-1$ & V & $O P-1$ & V & $O P-1$ & V & $O P-1$ \\
\hline 0 & $2.6 \pm 0.2$ & $2.6 \pm 0.1$ & $2.8 \pm 0.3$ & $2.6 \pm 0.1$ & $4.6 \pm 0.3$ & $4.3 \pm 0.5$ & $130 \pm 1$ & $131 \pm 5$ & $97 \pm 3$ & $96 \pm 3$ \\
\hline 1 & $2.6 \pm 0.1$ & $2.6 \pm 0.1$ & $5.9 \pm 1.0$ & $2.8 \pm 0.6^{*}$ & $6.0 \pm 1.2$ & $5.1 \pm 0.5$ & $129 \pm 5$ & $132 \pm 7$ & $89 \pm 6$ & $94 \pm 7$ \\
\hline 2 & $2.7 \pm 0.1$ & $2.6 \pm 0.2$ & $7.3 \pm 1.0$ & $2.9 \pm 0.4^{*}$ & - & - & - & - & - & - \\
\hline 3 & $2.5 \pm 0.2$ & $2.6 \pm 0.1$ & $7.1 \pm 1.0$ & $3.1 \pm 0.5^{*}$ & $6.2 \pm 1.4$ & $4.2 \pm 0.4^{*}$ & $143 \pm 5$ & $145 \pm 1$ & $100 \pm 6$ & $102 \pm 2$ \\
\hline 4 & $2.5 \pm 0.1$ & $2.6 \pm 0.1$ & $6.4 \pm 1.0$ & $2.8 \pm 0.4^{*}$ & - & - & - & - & - & - \\
\hline
\end{tabular}

Rats were subjected to $60 \mathrm{~min}$ bilateral occlusion of renal artery, and then allowed to recover for up to 4 d. $250 \mu \mathrm{g}$ OP-1/kg $(n=24)$ or vehicle buffer $(n=24)$ was given $10 \mathrm{~min}$ before and 24,48 , and $72 \mathrm{~h}$ after release of clamps. Electrolytes were measured in serum of vehicle $(V)$ and treated rats $(O P-1)$ at indicated time intervals. Data are shown as mean \pm SD from three separate experiments. $* P<0.01$ versus vehicle. 

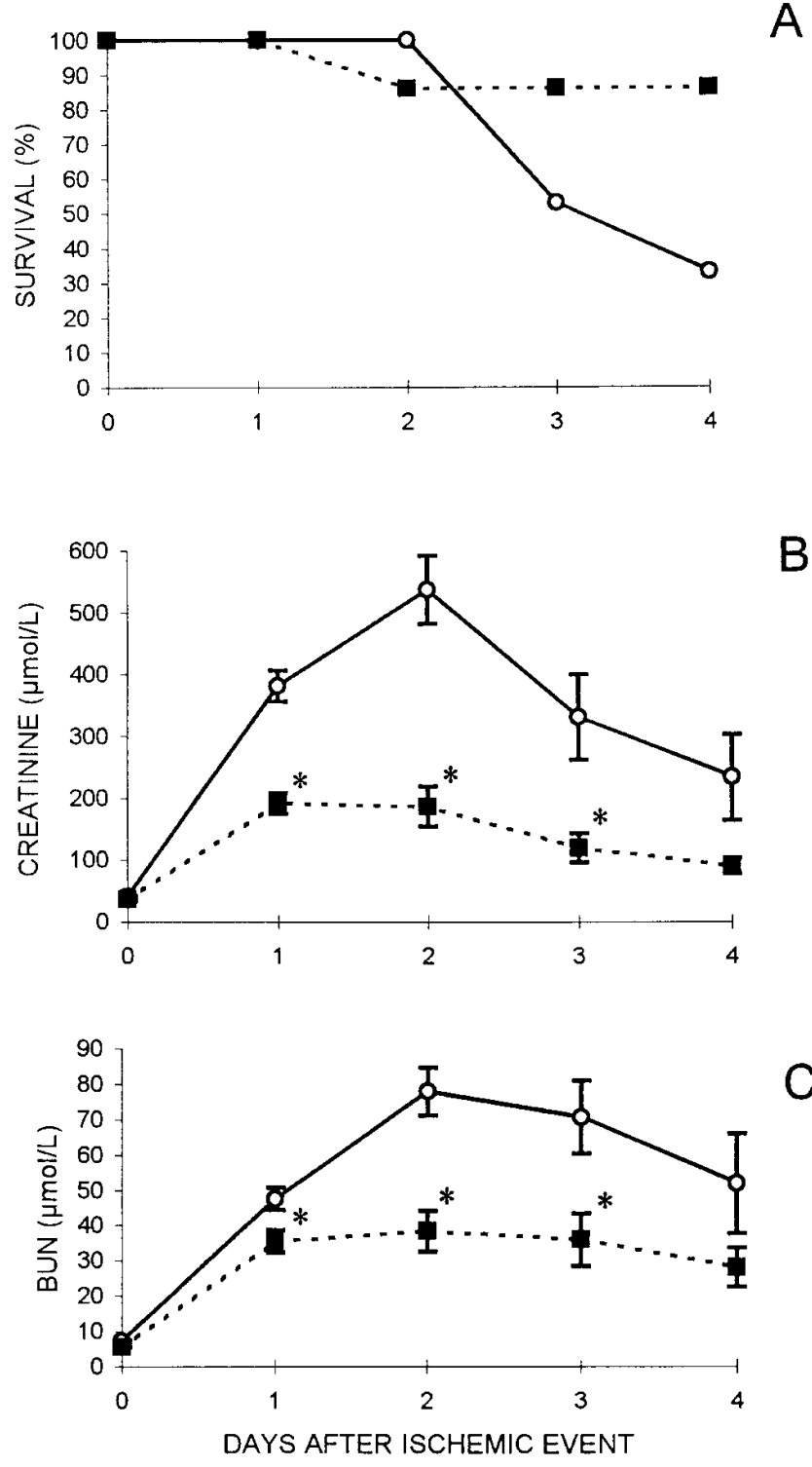

Figure 2. Prophylactic effect of OP-1 on survival rate $(A)$, creatinine $(B)$, and BUN $(C)$ in renal ischemia. Rats were subjected to $60 \mathrm{~min}$ bilateral occlusion of renal artery, and then allowed to recover for up to $4 \mathrm{~d} .250 \mu \mathrm{g}$ OP- $1 / \mathrm{kg}(\mathbf{\square} ; n=23)$ or vehicle acetate buffer, $\mathrm{pH}=4.5$ $(\bigcirc ; n=15)$ was given $10 \mathrm{~min}$ before, and then at 24,48 , and $72 \mathrm{~h}$ after release of clamps. Mortality $(A)$ was $73 \%(11 / 15)$ in vehicle-treated and $8 \%(2 / 23)$ in OP-1-treated rats, respectively. Data shown as mean \pm SEM. $* P<0.001$ versus vehicle-treated rats.

High serum levels of OP-1 were achieved immediately after intravenous injection followed by a steady decline with a half life of $\sim 30 \mathrm{~min}$ as determined using a human OP-1-specific ELISA. Approximately $1.4 \mu \mathrm{g}$ OP- $1 / \mathrm{ml}$ was present in the circulation $1 \mathrm{~min}$ after injecting a dose of $250 \mu \mathrm{g}$ OP-1/kg (Fig. 1

B

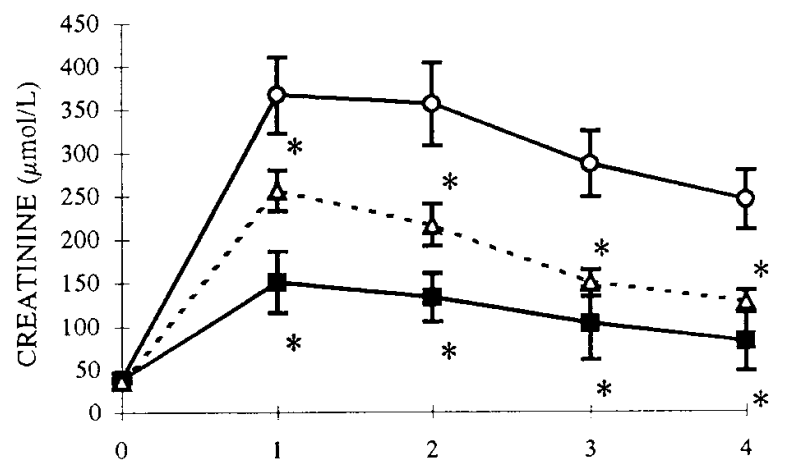

A

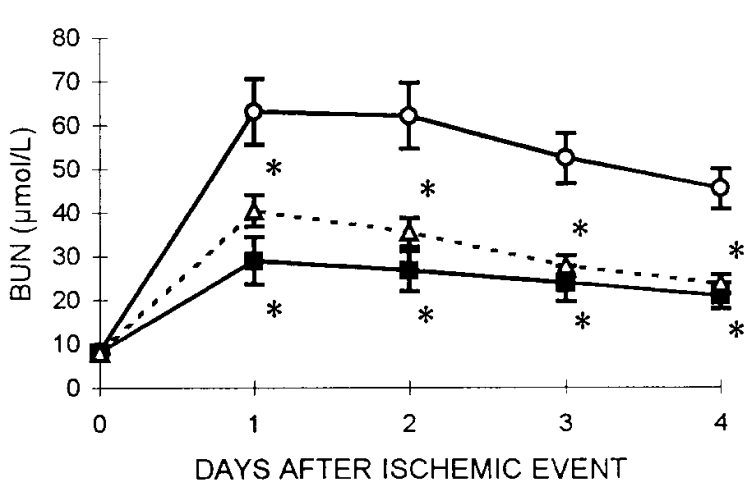

Figure 3. Therapeutic effect of OP-1 on creatinine $(A)$ and BUN $(B)$ in renal ischemia. Rats were subjected to $60 \mathrm{~min}$ bilateral renal ischemia, and then allowed to recover for up to $4 \mathrm{~d}$. Vehicle acetate buffer, pH $4.5(\bigcirc ; n=8)$, and $250 \mu \mathrm{g}$ OP-1 $/ \mathrm{kg}$ bw were given $1 \mathrm{~h}(\mathbf{\square}$; $n=8)$ or $16 \mathrm{~h}(\triangle ; n=8)$ after release of clamps and then at 24,48 , and $72 \mathrm{~h}$ thereafter. Data shown as mean \pm SEM. $* P<0.001$ for OP-1 $1 \mathrm{~h}$ versus vehicle-treated rats, and $P<0.01$ for OP-1 $16 \mathrm{~h}$ versus vehicle-treated rats.

$A$ ), which is $\sim 1,000$-fold higher than normal endogenous circulating OP-1 levels $(0.1-0.5 \mathrm{ng} / \mathrm{ml})$. Western blot analysis demonstrated that OP-1 remained intact in the serum, assayed at $30 \mathrm{~min}$ after systemic administration.

Based on studies using both low and high specific activity of radiolabeled OP-1, $\sim 270$ and $140 \mathrm{ng}$ OP-1/g kidney was available to the cortex and medulla, respectively, when $250 \mu \mathrm{g}$ OP-1/kg was injected (Fig. $1 B$ ). Autoradiographs of tissue sections revealed that OP-1 bound predominantly to both the parietal and visceral epithelium of the glomeruli and to the proximal tubule epithelium (data not shown).

OP-1 bound specifically to purified plasma membrane fractions of cortex and medulla. Cortex had more OP-1-binding sites than medulla, as demonstrated by ${ }^{125}$ I-labeled OP-1 binding, which could not be competed with unlabeled BMP-2, TGF- $\beta 1$, CDMP-1/GDF-5, EGF, IGF-1, bFGF, and PDGF (Fig. 1 C). The presence of OP-1 type I receptors, ALK-2, -3,

Figure 4. Effect of OP-1 on renal histology (H\&E) in rats subjected to $60 \mathrm{~min}$ of renal ischemia. Comparison of typical histology from animals treated with vehicle (acetate buffer, right) or OP-1 (left) at $2(A$ and $B), 24(C$ and $D), 72(E$ and $F)$, and $120 \mathrm{~h}(G$ and $H)$ after reperfusion; 5×, H\&E staining. Arrows in $D$ indicate the area of blood congestion. * in $D, F, H$ indicates infarction. Histomorphometric analysis displayed in Table II. 
hr OP-1

2
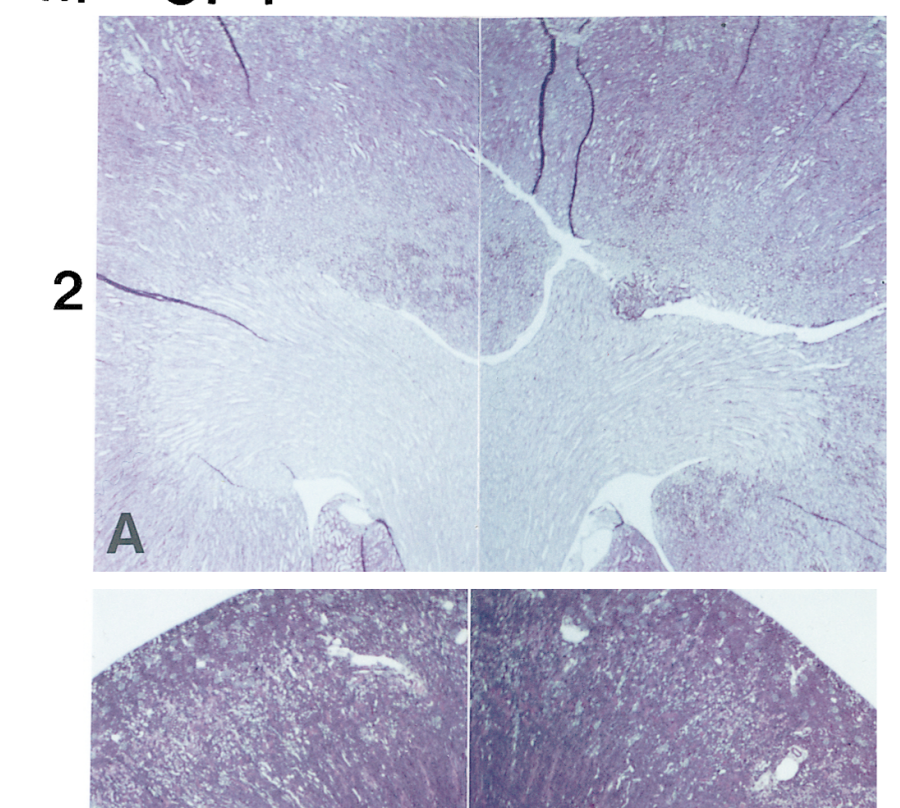

24

72
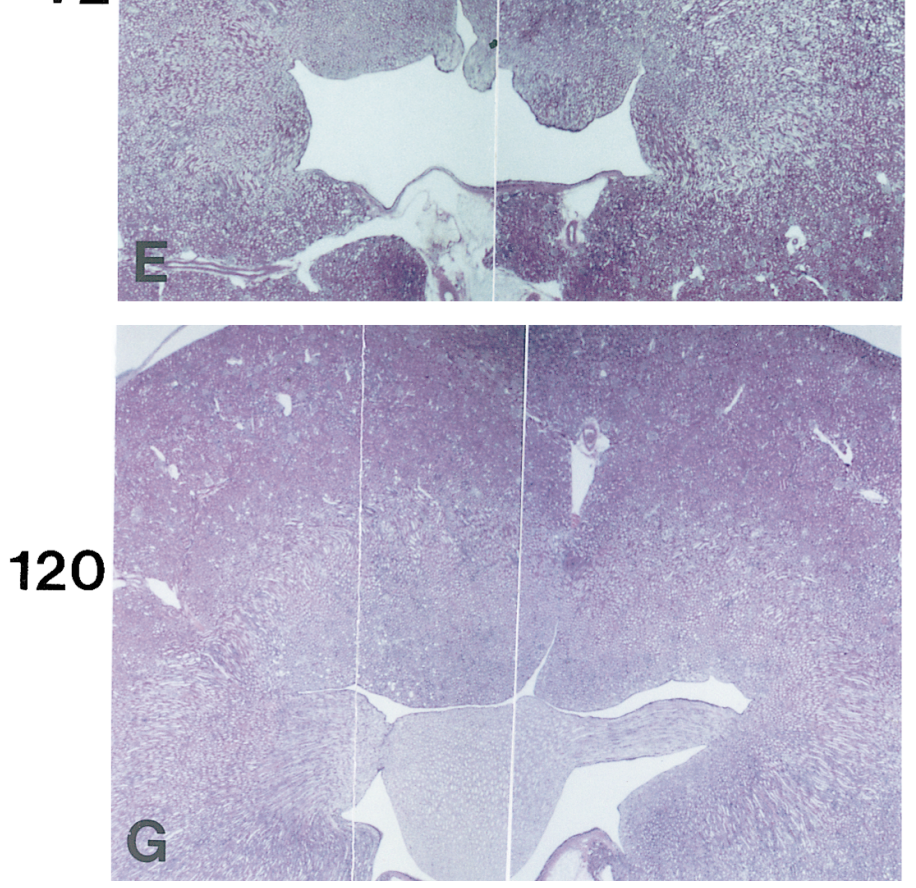

\section{CONTROL}
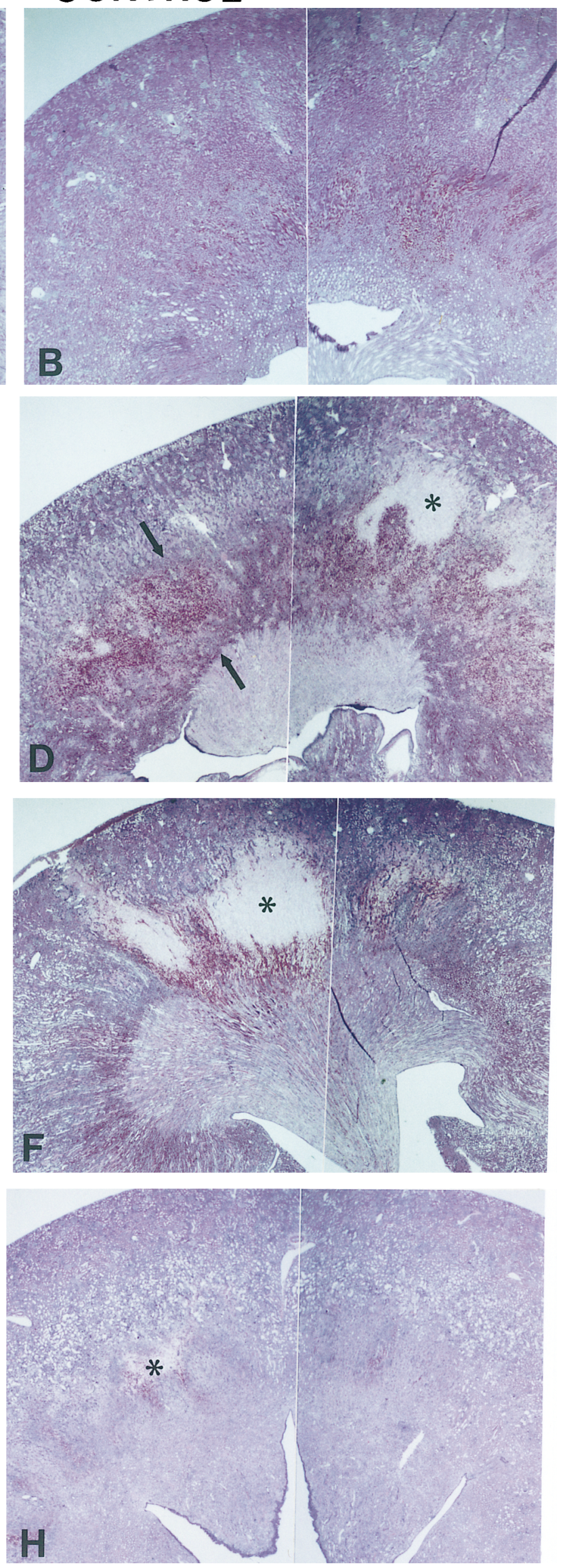
Table II. Effect of OP-1 on Renal Histology in Rats after Ischemia

\begin{tabular}{|c|c|c|c|c|}
\hline \multirow[t]{2}{*}{ Treatment } & \multicolumn{2}{|c|}{ Necrosis* } & \multicolumn{2}{|c|}{ Infarction* } \\
\hline & $\begin{array}{l}\text { Positivel } \\
\text { total }\end{array}$ & $\begin{array}{c}\% \text { area } \\
\text { Median (range) }\end{array}$ & $\begin{array}{l}\text { Positivel } \\
\text { total }\end{array}$ & $\begin{array}{c}\% \text { area } \\
\text { Median (range) }\end{array}$ \\
\hline Vehicle & $28 / 32$ & $5.5(0.0-32.8)$ & $26 / 32$ & $10.8(0.0-39.3)$ \\
\hline OP-1 & $16 / 32$ & $0.3(0.0-33.5)$ & $14 / 32$ & $0.0(0.0-36.6)$ \\
\hline$P$ & $<0.003^{\ddagger}$ & $<0.002^{\S}$ & $<0.005^{\ddagger}$ & $<0.0001^{\S}$ \\
\hline
\end{tabular}

Rats $(n=64)$ were subjected to 60 min bilateral occlusion of renal artery followed by reperfusion. Eight rats in vehicle and OP-1-treated groups were killed at $24,48,72$, and $120 \mathrm{~h}$, and subjected to histomorphometric analyses. Whole kidney area of two sections per rat from eight animals per each time point were quantitatively scored, as described in Methods. *Summarized necrosis and infarction data are presented as $\%$ area median. ${ }^{\ddagger}$ Chi-square test. ${ }^{\S}$ Mann-Whitney U test.

and -6 , and a BMP type-II receptor as detected by RT-PCR further supports the specificity of OP-1 binding in the kidney (data not shown).

Prophylactic and therapeutic effects. In a typical experiment, at $24 \mathrm{~h}$ after reperfusion, serum creatinine $(\mathrm{Cr})$ and BUN levels were increased 8-10 times above normal values in rats with ARF that received vehicle acetate buffer $(500 \mu \mathrm{l} ; \mathrm{pH}$ 4.5; Fig. 2, $B$ and $C$ ). Intravenous injection of $250 \mu \mathrm{g} \mathrm{OP}-1 / \mathrm{kg}$ at $10 \mathrm{~min}$ before clamping and then at $24 \mathrm{~h}$ intervals up to $72 \mathrm{~h}$ after reperfusion, dramatically decreased the mortality rate (Fig. $2 A$ ), and strongly suppressed the elevation of serum $\mathrm{Cr}$, BUN (Fig. 2, $B$ and $C$ ), phosphorus and potassium values (Table I), as compared to vehicle-treated rats. Serum sodium and chloride values were unchanged in all animals (Table I). Vehicle alone did not influence the kidney function in rats with ARF as compared to ARF rats that received none (data not shown). The OP-1 dose that successfully protected the kidney against ischemic injury varied with age of the animal and severity of ischemia and reperfusion, and was within a range of $50-250 \mu \mathrm{g} / \mathrm{kg}$. GFR measured at $24 \mathrm{~h}$ after reperfusion was higher in OP-1-treated rats; sham rats had a GFR $(\mathrm{ml} / \mathrm{min})$ of 4.7 \pm 0.8 ; vehicle-treated ARF rats had a GFR of $0.25 \pm 0.11$; and OP-1-treated rats had a GFR of $0.45 \pm 0.17(P<0.05$ versus ARF). To examine the therapeutic potential of OP-1 for the treatment of established ARF, we administered OP-1 either at 1 or $16 \mathrm{~h}$ after reperfusion. Both OP-1 treatment groups showed lower serum $\mathrm{Cr}$ and BUN values (Fig. 3, $A$ and $B$ ). The reduction of serum $\mathrm{Cr}$ and $\mathrm{BUN}$ was more dramatic in rats with OP-1 administered at $1 \mathrm{~h}$ than those receiving OP-1 at $16 \mathrm{~h}$ after reperfusion (Fig. 3). These results indicate that OP-1 protects against loss of kidney function in ischemia, as measured by serum biochemical parameters.

Protection against kidney damage. Histological analysis of kidney sections from rats with ARF indicated that morphologic changes had occurred in the $\mathrm{S}_{3}$ zone (Fig. 4). At $2 \mathrm{~h}$ after reperfusion, vehicle-treated kidneys showed signs of congestion (Fig. $4 \mathrm{~B}$ ), which led to large areas of parenchymal infarction and necrosis when examined at 24, 72, and $120 \mathrm{~h}$ after reperfusion (Fig. 4, $D, F$, and $H$ ). Animals given OP-1 before ischemia, however, exhibited little or no congestion (Fig. 4, $A$ and $C$ ) and had less infarction (Fig. 4, $E$ and $G$ ); 28 of 32 vehicle-treated kidneys and 16 of 32 OP-1-treated kidneys had white infarction (necrosis) and 26 of 32 vehicle-treated and 14
Table III. Effect of OP-1 on Renal Tubules in Noninfarcted Kidney Areas after Ischemia

\begin{tabular}{cccc}
\hline $\begin{array}{c}\text { Days post } \\
\text { injury }\end{array}$ & $\begin{array}{c}\text { Total tissue area } \\
\text { TAr(mm })\end{array}$ & $\begin{array}{c}\text { Dilated tubular area } \\
\text { (\%) DAr/ } \\
\text { TAr-(NAr+IAr) }\end{array}$ & $\begin{array}{c}\text { Plugged tubular area } \\
(\%) \text { PAr/ } \\
\text { TAr-(NAr+IAr) }\end{array}$ \\
\hline $\begin{array}{c}\text { Day I } \\
\text { Vehicle }\end{array}$ & $88 \pm 9$ & $51 \pm 16$ & $31 \pm 15$ \\
OP-1 & $86 \pm 8$ & $48 \pm 19$ & $28 \pm 16$ \\
Day 2 & & & \\
Vehicle & $91 \pm 11$ & $56 \pm 16$ & $21 \pm 5$ \\
OP-1 & $100 \pm 10$ & $53 \pm 5$ & $15 \pm 4^{*}$ \\
Day 5 & & & \\
Vehicle & $111 \pm 22$ & $53 \pm 16$ & $20 \pm 8$ \\
OP-1 & $105 \pm 10$ & $56 \pm 7$ & $11 \pm 4 *$ \\
\end{tabular}

Rats $(n=48)$ were subjected to 60 min bilateral occlusion of renal artery followed by reperfusion. Eight rats in vehicle and OP-1-treated groups were killed at day 1,2, and 5, and subjected to histomorphometric analyses as described in Methods. Dilated $(D A r)$ or plugged tubular $(P A r)$ area was expressed as a percent of the total area (TAr) excluding the infarcted $(I A r)$ and necrotic $(N A r)$ areas. Data are presented as mean \pm SEM. $* P<0.05$ versus vehicle.

of 32 OP-1-treated rats had red infarction (Table II; Fig. 4, $H$ and $G)$. Histomorphometric analyses showed that 6 and $11 \%$ of the kidney section area in vehicle-treated rats and $0.3 \%$ and 0 of OP-1-treated rats had white or red infarction, respectively (Table II). In the kidney area not affected by infarction and necrosis, $\sim 50 \%$ of tubules were dilated both in vehicle- and OP-1-treated rats at 1-5 d after injury (Table III). However, fewer tubules plugged with desquamated epithelial cells, cell debris, and cast matrix were found in OP-1-treated rats, as compared with vehicle-treated animals on days 2 and 5 after injury (Table III). The analysis of peritubular capillaryderived smooth muscle cells revealed that at $24 \mathrm{~h}$ after injury, approximately fivefold more cells in the $\mathrm{S}_{3}$ zone of OP-1treated kidneys expressed $\alpha$-actin (Fig. 5, $A$ and $B$; Table IV) and $\mathrm{IgG}$ myosin (data not shown), as compared to vehicle-

Table IV. Effects of OP-1 on Cell Proliferation and Maintenance of Smooth Muscle Cell Phenotype after Ischemia

\begin{tabular}{|c|c|c|c|c|c|}
\hline \multirow[b]{2}{*}{ Treatment } & \multicolumn{2}{|c|}{ Cortex } & \multicolumn{3}{|c|}{$\mathrm{S}_{3}$ Zone } \\
\hline & $\begin{array}{c}\text { Total cells } \\
\text { counted }\end{array}$ & PCNA+ & $\begin{array}{c}\text { Total cells } \\
\text { counted }\end{array}$ & PCNA+ & SMA+ \\
\hline & & $\%$ & & $\%$ & \\
\hline Vehicle & 4058 & $18 \pm 4$ & 3320 & $25 \pm 4$ & $5 \pm 1$ \\
\hline OP-1 & 4643 & $25 \pm 4^{*}$ & 4130 & $40 \pm 6 * *$ & $23 \pm 5 * *$ \\
\hline
\end{tabular}

Rats $(n=16)$ were subjected to 60 min bilateral occlusion of renal artery followed by reperfusion. Eight rats in control and OP-1-treated groups were killed and subjected to histology. PCNA-positive epithelial cells in proximal tubular region and $\alpha$-actin-positive smooth muscle cells in the peritubular capillary were counted on kidney sections per rat $(n=8)$ obtained at $24 \mathrm{~h}$ after an ischemic insult and expressed as a percentage of total cell number in cortex and/or $S_{3}$ zone. ${ }^{*} P<0.05$ versus vehicle. $* * P<0.01$ versus vehicle. 

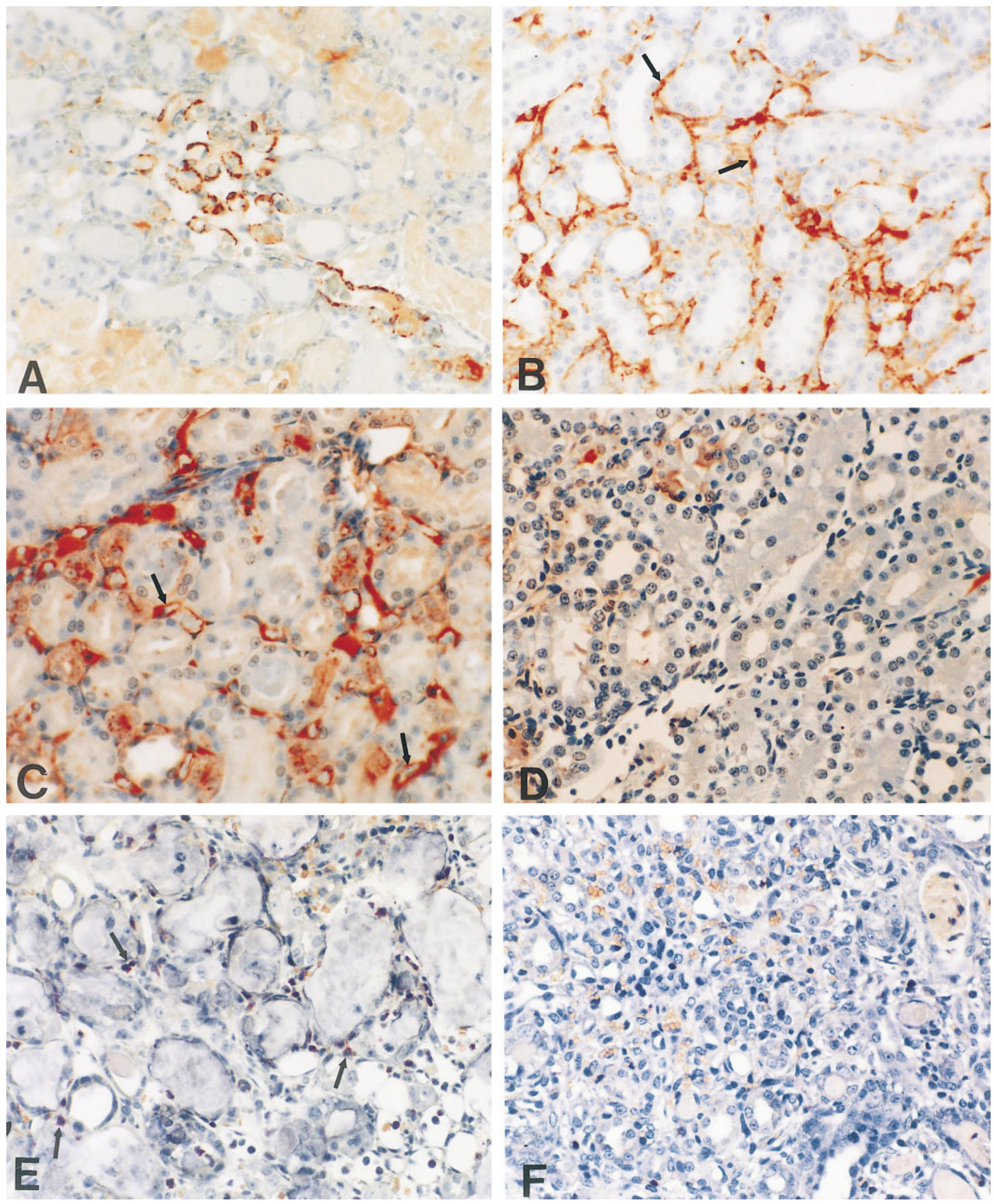

D.

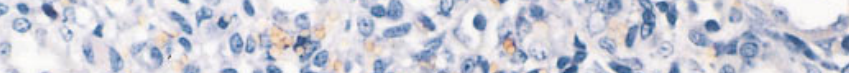

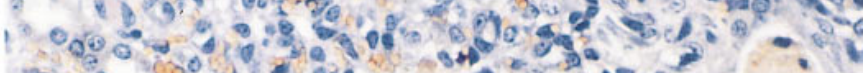

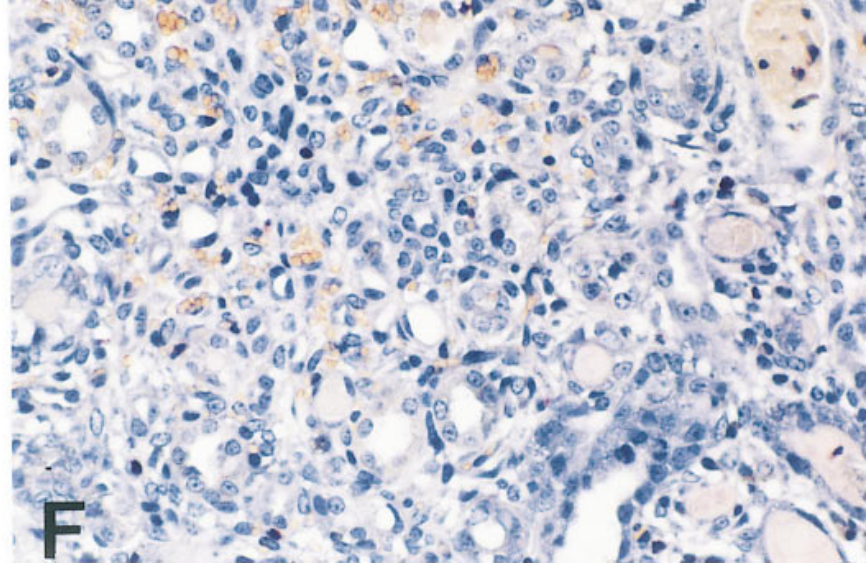

Figure 5. Staining of SMA ( $A$ and $B)$, ICAM-1 $(C$ and $D)$, and neutrophils $(E$ and $F)$ in the $\mathrm{S}_{3}$ kidney zone of rats subjected to 60 min of renal ischemia. Animals were treated with vehicle $(A, C$, and $E)$ or $250 \mu \mathrm{g} \mathrm{OP}-1(B, D$, and $F) 10 \mathrm{~min}$ before ischemia and sections analyzed at $24 \mathrm{~h}(A$, $B, E$, and $F)$ and at $8 \mathrm{~h}(C$ and $D)$ after injury. Arrows in $B$ indicate red staining for SMA and in $C$, for ICAM-1. Accumulation of neutrophils $(E$, arrows) was detected by naphthol AS-D-chloroacetate esterase staining, $\times 200$. 


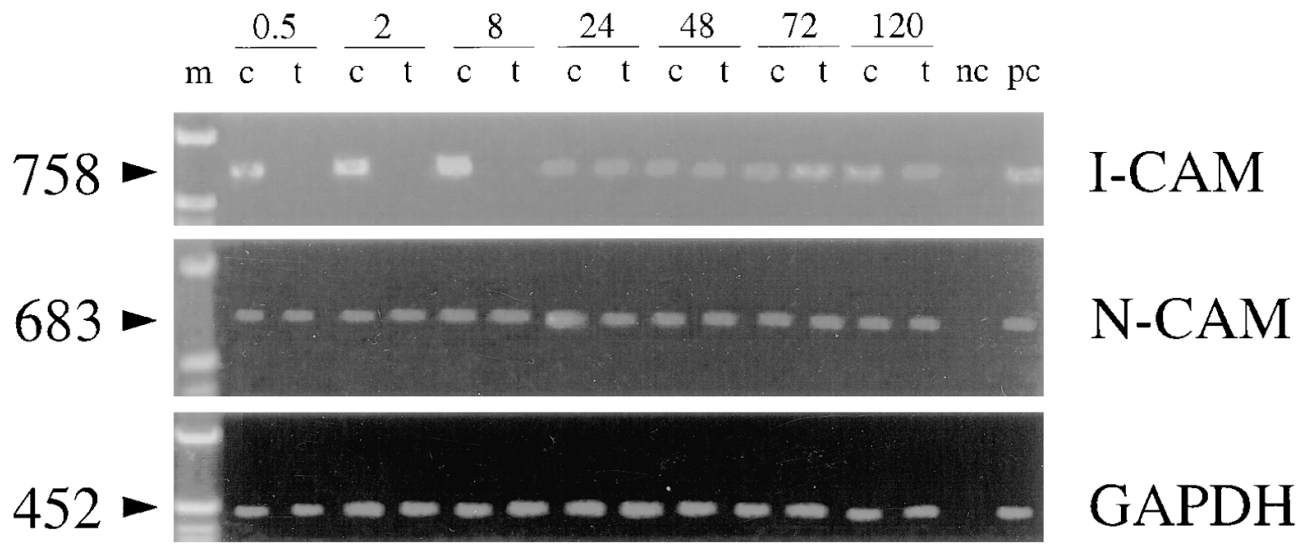

Figure 6. I-CAM (ICAM-1) and N-CAM mRNA expression in kidneys of rats subjected to 60 min of renal ischemia. Vehicle(c) and OP-1-treated $(t ; 250 \mu \mathrm{g} /$ $\mathrm{kg}$ ) animals were killed at $0.5,2$, $8,24,48,72$, and $120 \mathrm{~h}$ (top) after reperfusion. Whole kidney RNA was isolated, cDNA was synthesized and tested by RT-PCR. Reactions without DNA were used as negative control $(n c)$ and rat embryonal cDNA was used as a positive control $(p c)$. Product sizes are indicated at left.

treated kidneys, suggesting that OP-1 therapy supports the maintenance of vascular SMC phenotype. Cell proliferation evaluated by PCNA staining indicated an increase in proximal tubule cell growth in cortex and outer medulla of OP-1treated rats (Table IV). In animals treated $1 \mathrm{~h}$ after reperfusion, OP-1 had a similar protective action on kidney histology.

\section{CORTEX}
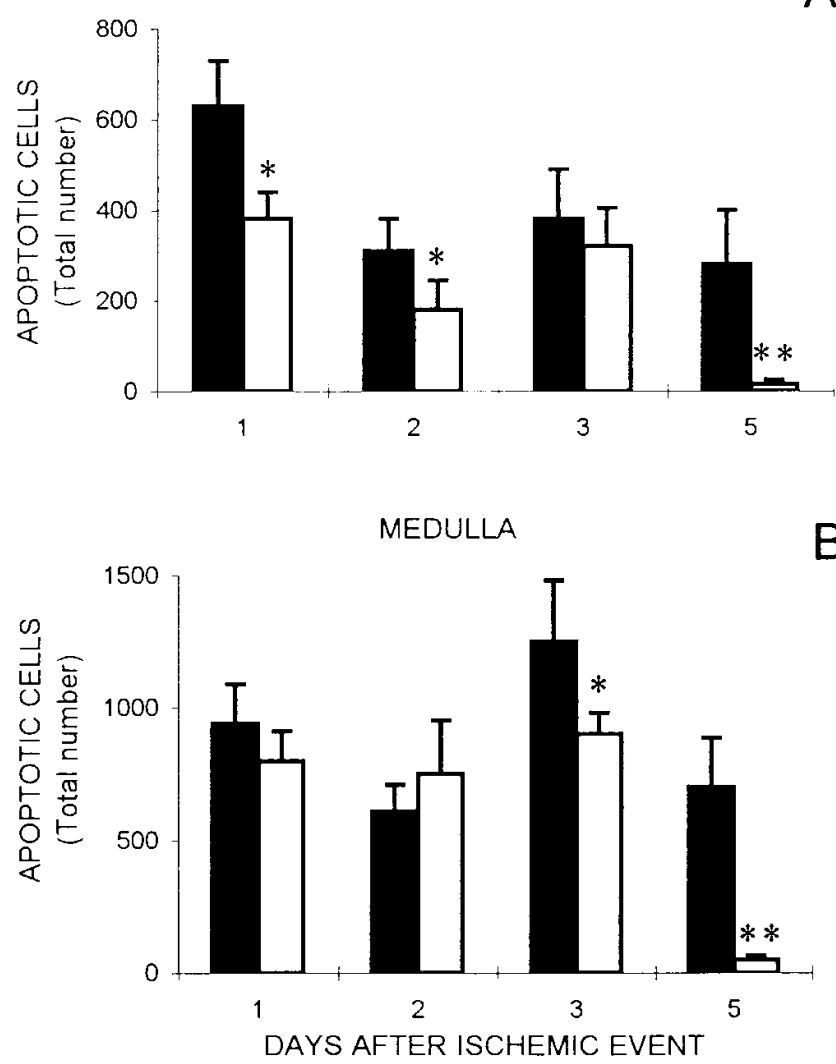

Figure 7. Effect of OP-1 on apoptotic cell counts in rats subjected to $60 \mathrm{~min}$ of renal ischemia. Vehicle (black columns; $n=8 / \mathrm{d}$ ) and OP-1treated (white columns; $250 \mu \mathrm{g} / \mathrm{kg}$ bw; $n=8 / \mathrm{d}$ ) animals were killed at $1,2,3$, and $5 \mathrm{~d}$ after reperfusion and the total number of apoptotic cells was detected (TACS 2 TdT system) in cortex $(A)$ and medulla $(B)$ of kidney sections. Data shown as mean \pm SEM. $* P<0.05$ and ** $P<0.01$ versus vehicle-treated rats.
In animals treated $16 \mathrm{~h}$ after reperfusion, the structural damage was similar to vehicle-treated animals at $24 \mathrm{~h}$ after injury (data not shown).

Suppression of inflammation. As ICAM-1 has been reported to play an important role during the onset of ARF, we determined the effect of OP-1 on the expression of ICAM-1 at different time points after ischemia and reperfusion. OP-1 treatment $10 \mathrm{~min}$ before ischemia attenuated the expression of ICAM-1, as determined by molecular and histochemical analyses of kidneys obtained at $30 \mathrm{~min}, 2$, and $8 \mathrm{~h}$ after reperfusion (Fig. 5, $C$ and $D$; Fig. 6). Significant neutrophil accumulation in vehicle-treated rats was observed at $24 \mathrm{~h}$ after reperfusion in the $\mathrm{S}_{3}$ zone (Fig. 5, $E$ and $F$ ). In contrast, rats treated with OP-1 had dramatically decreased neutrophil accumulation $(232 \pm 47$ cells $/ \mathrm{mm}^{2}$ in vehicle versus $9 \pm 3$ cells $/ \mathrm{mm}^{2}$ in OP- 1 group; $n=$ $8 ; P<0.01)$. Neutrophil activity in the kidney was monitored by measuring the total tissue MPO. Administration of OP-1 $1 \mathrm{~h}$ after reperfusion, decreased the MPO activity approximately threefold, as determined at $24 \mathrm{~h}$ after reperfusion (MPO/ $\mu \mathrm{g} /$ wet kidney: $37.3 \pm 16.5$ in vehicle versus $12.8 \pm 7.6$ in OP-1-treated kidneys; $n=8 ; P<0.01$ ).

Reduction of apoptosis. At days 1 and 2 after injury, there were no differences in the number of apoptotic cells in the medulla of both OP-1 and vehicle-treated kidneys (Fig. 7, $A$ and $B$; Fig. 8, $a$ and $c$ ). However, a reduction in the number of apoptotic cells was observed in the cortex of OP-1 treated rats (Fig. 7 A). $5 \mathrm{~d}$ after injury, OP-1 treatment resulted in a dramatic reduction of apoptotic cells attached to basement membrane both in tubules of the cortex and medulla (Figs. 7, $A$ and $B$; $8 d$ ), whereas numerous apoptotic cells were still observed in the lumen of renal tubules of vehicle-treated rats (Fig. $8 b$ ).

Growth factor expression. We examined the expression of OP-1, TGF- $\beta 1$, EGF, and IGF-1 in the whole kidney in the period of $30 \mathrm{~min}$ to $5 \mathrm{~d}$ after injury by RT-PCR. At $24 \mathrm{~h}$ and thereafter, OP-1 transcripts were reduced in all animals regardless of treatment (Fig. 9). A similar trend was observed for EGF and IGF-1; however, TGF- $\beta 1$ expression was maintained and appeared to increase at $48 \mathrm{~h}$ after reperfusion injury (Fig. 9). OP-1 mRNA was predominantly localized to collecting duct epithelium of the medulla in sham-operated animals (Fig. $10 \mathrm{~B}$ ), and no apparent transcripts were found in the cortex (Fig. $10 \mathrm{~A}$ ). At $2 \mathrm{~h}$ after injury, however, OP-1 mRNA expression was found in glomeruli and convoluted tubules of the cortex, both in vehicle (data not shown) and OP-1-treated rats (Fig. 10, $C$ and $D$ ). 

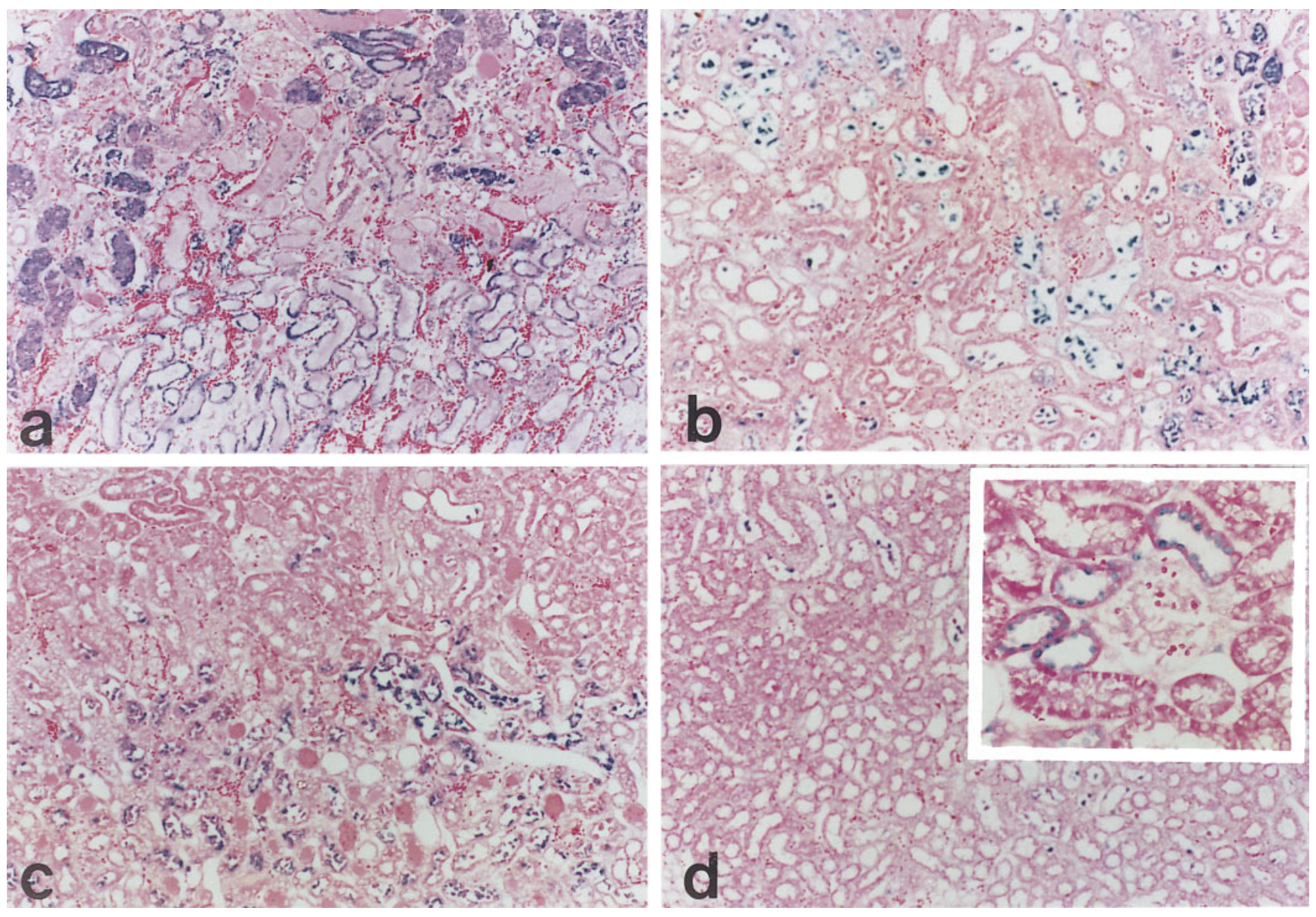

Figure 8. Histological appearance of apoptotic cells (blue) in rats subjected to $60 \mathrm{~min}$ of renal ischemia and treated with vehicle $(A=24 \mathrm{~h}, B=$ $120 \mathrm{~h})$ or OP-1 $(C=24 \mathrm{~h}, D=120 \mathrm{~h}), \times 40$. Insert indicates apoptotic cells attached to basement membranes of kidney tubules, $\times 200$.

\section{Discussion}

In the present study, we show that systemically administered recombinant human osteogenic protein-1 (OP-1/BMP-7) protects kidney structure and function and increases the survival after 60 min bilateral renal artery occlussion injury in rats. The demonstration that OP-1 improves renal function when administered 1 or $16 \mathrm{~h}$ after reperfusion suggests that OP-1 may have a therapeutic potential in the treatment of ARF associated with ischemia. Because ischemia is often not predictable in man, a therapeutic intervention that has a capacity to either minimize injury and/or effect a more rapid recovery after the insult would be beneficial.

Kidney has a capacity to repair and recover its function after ischemia/reperfusion injury by recapitulating the molecular and cellular events that are associated with nephrogenesis $(5$, 15). It is possible that OP-1, a morphogenic protein involved in the induction of metanephric mesenchyme during development (25), may influence migration, growth, and differentiation of tubular epithelial cells after ischemia. The effective dose of systemically administered OP-1 (250 $\mu \mathrm{g}$ per $\mathrm{kg}$ bw) and its bioavailability to OP-1-specific receptors in the kidney show that it reaches the target tissue and stimulates tubular epithelial cell proliferation after reperfusion. Comparable amounts of OP-1 that reached the kidney were effective in modulating growth and differentiation of proximal tubule cells in vitro. Human proximal tubular epithelial cells respond to OP-1 by enhancing cell growth and maintaining the expression of markers that are characteristic of an epithelial phenotype in long-term cultures (35).

Several growth factors, including TGF- $\beta$, IGF-1, EGF, and HGF have been shown to accelerate the recovery of kidney function after ischemia and reperfusion $(16,17)$. Local production of these growth factors and respective receptors have been shown to be increased within $24 \mathrm{~h}$ after reperfusion, and then, subsequently, reduced during the recovery phase (36, 37 ). We show here that, like other growth factors, OP-1 expression declines at $24 \mathrm{~h}$ and, henceforth, after injury.

The demonstration that systemically administered OP-1 downregulates ICAM-1 production and reduces the accumulation of neutrophils and tissue myeloperoxidase activity in rats with ARF suggests that, in addition to its morphogenic role, OP-1 may provide cytoprotection against inflammatory cytokine-mediated injury. In support of this observation, we found that OP-1 is able to inhibit inflammatory cytokine (IL-1 and TNF- $\alpha$ )-mediated ICAM-1 production in proximal tubular epithelial and vascular SMC in culture (35). Previous studies have shown that systemic administration of OP-1 is capable of protecting heart and brain in rat ischemic models by inhibiting neutrophil adhesion to vascular endothelium $(38,39)$. We suggest that OP-1 is a negative regulator of ICAM expression in vivo and, thus, may have a role in preventing neutrophil-medi- 


\section{$\begin{array}{lllllll}0.5 & 2 & 8 & 24 & 48 & 72 & 120\end{array}$

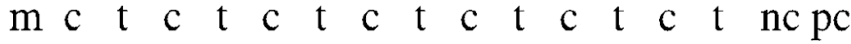

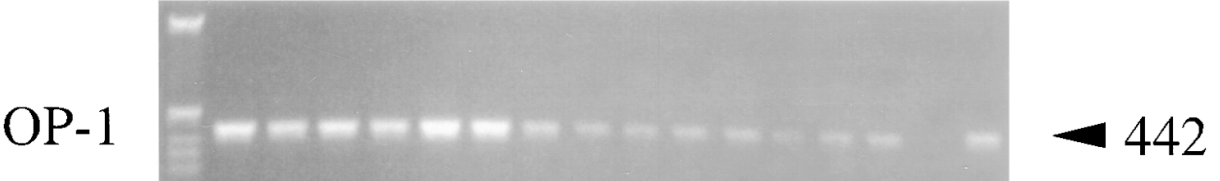

\section{TGF-B1}

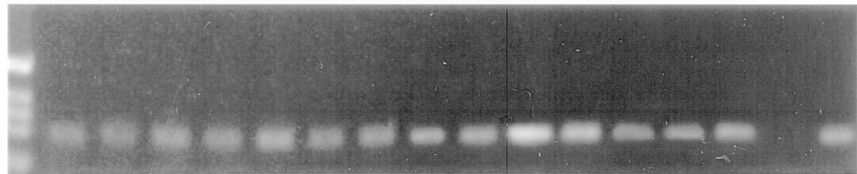

EGF

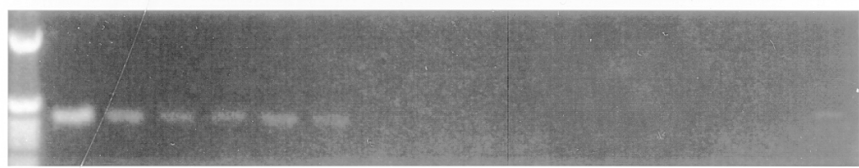

IGF1

GAPDH

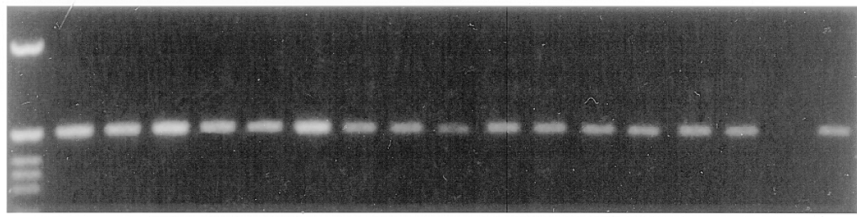

$-506$

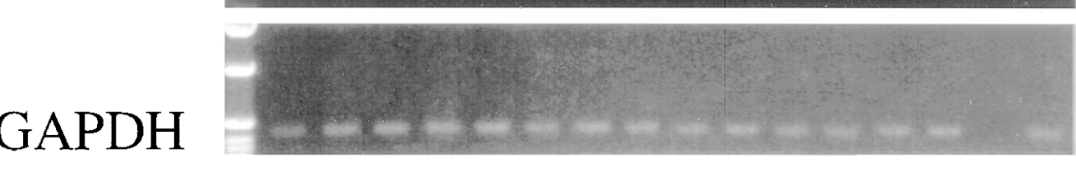

452
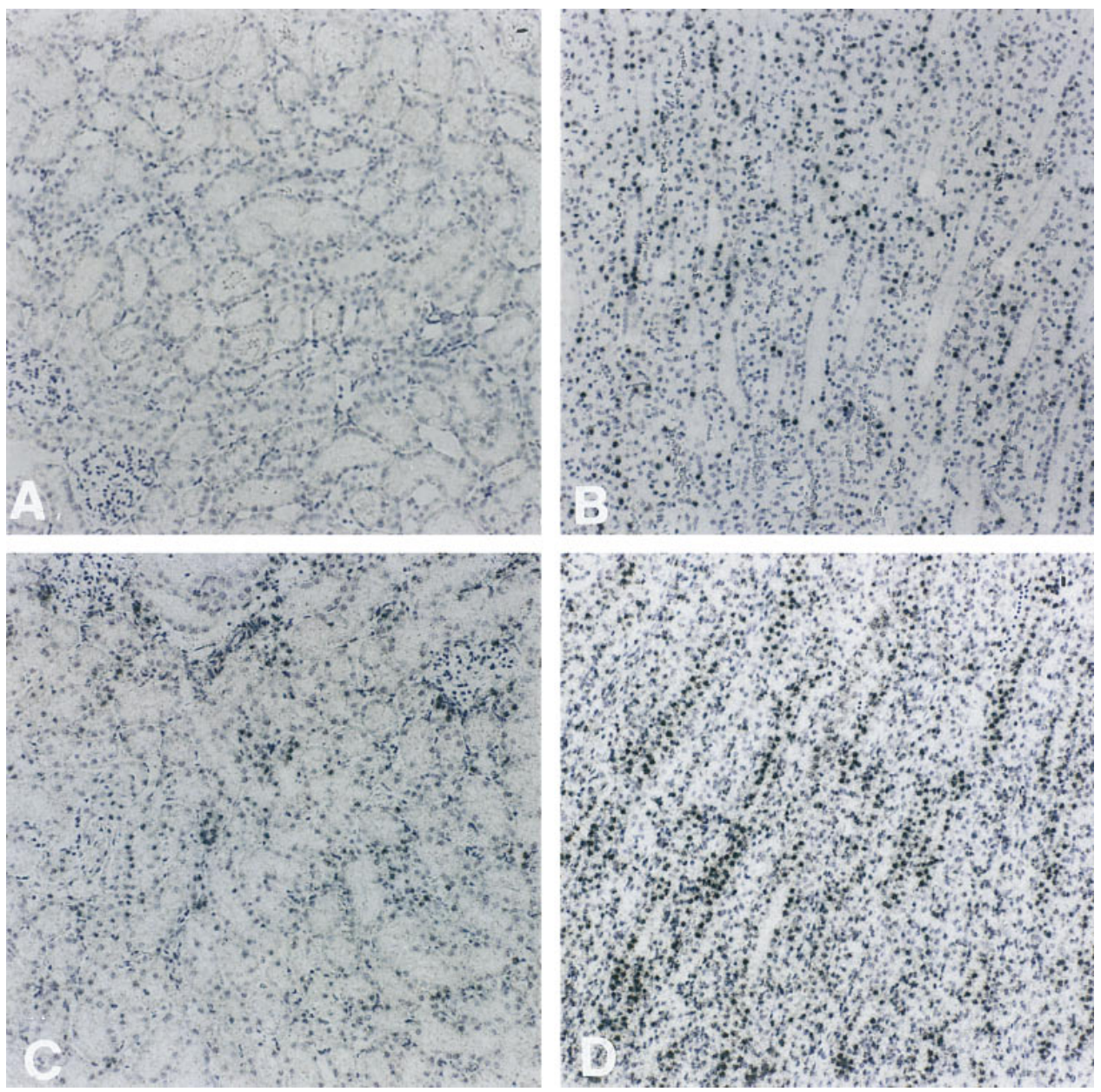

298

436

Figure 9. Growth factor expression in kidneys of rats subjected to $60 \mathrm{~min}$ of renal ischemia. Vehicle $(c)$ and OP-1-treated $(t ; 250 \mu \mathrm{g}$ OP- $1 / \mathrm{kg})$ animals were killed at $0.5,2,8,24,48,72,120 \mathrm{~h}$ (top) after reperfusion. Whole kidney RNA was isolated; cDNA was synthesized and analyzed by RT-PCR. Reactions without CDNA were used as a negative control $(n c)$ and rat placental cDNA was used as a positive control $(p c)$. Product sizes are indicated at right.
Figure 10. OP-1 mRNA expression in cortex (left) and medulla (right) of sham animals ( $A$ and $B$ ) and rats subjected to $60 \mathrm{~min}$ of renal ischemia. Kidney sections of rats treated with $250 \mu \mathrm{g}$ OP- $1 / \mathrm{kg}$ ( $C$ and $D)$ at $2 \mathrm{~h}$ after reperfusion were exposed to OP-1 rat-specific antisense RNA probes, and counterstained with haematoxylin, $\times 200$. 
ated tissue damage. Administration of anti-ICAM-1 antibodies to rats after renal ischemia was shown to protect kidney damage against ischemic injury (13). A recent report suggests that the beneficial effect of $\alpha$-melanocyte-stimulating hormone against renal ischemic injury may in part be mediated by its action on downregulation of ICAM-1 and IL-8 (40).

The finding that OP-1 maintains the expression of SMC phenotype in peritubular capillaries of the $S_{3}$ zone suggests that this may contribute to prevent structural damage in reperfusion injury (4). Recent data that OP-1 improves renal function by improving GFR, RBF, and urine flow rate in norepinephrine-induced ARF in rats support this notion (41). Moreover, studies on the effect of OP-1 on human renal artery SMC primary cultures showed that OP-1 maintains the expression of markers specific for SMC phenotype and protects against cytotoxicity induced by the ATP-depleting agent, antimycin A (42).

The rat model of renal ischemic insult also results in cell necrosis and apoptosis, as is evident after renal transplantation and ARF in man. Prevention of cell necrosis in the initial phase and reduction of apoptosis during the recovery period suggest that OP-1 may play a morphogenic role in promoting renal repair and regeneration after an ischemic insult. The process of recovery is faster in OP-1-treated kidneys, suggesting that OP-1 therapy might compensate for the loss of kidney function after injury. Taken together, our results indicate that OP-1 (a) improves renal function, $(b)$ minimizes tubular necrosis and tissue infarction, $(c)$ suppresses inflammation, $(d)$ maintains the expression of vascular SMC phenotype, and $(e)$ reduces programmed cell death. These beneficial effects of OP-1 may provide a basis for treatment of acute renal ischemic injury in man.

\section{Acknowledgments}

We thank D. Car, M. Palcic, K. Norton, D. Drager, and D. Costa for technical help in the animal studies. Thanks to C. Cohen, V. Sukhatme (Beth Israel Hospital, Boston, MA), and J. Kopp (NIDDK, National Institutes of Health, Bethesda, MD) for critical review of the manuscript.

This work was supported in part by grants from Croatian Ministry of Science and U.S.-Croatian joint board to S. Vukicevic.

\section{References}

1. Thadhani, R., M. Pascual, and J.V. Bonventre. 1996. Acute renal failure. N. Engl. J. Med. 334:1448-1460.

2. Lieberthal, W., and N.G. Levinsky. 1990. Treatment of acute tubular necrosis. Semin. Nephrol. 10:571-583.

3. Bonventre, J.V. 1993. Mechanisms of ischemic renal failure. Kidney Int. 43:1160-1178.

4. Conger, J.D., M.F. Schultz, F. Miller, and J.B. Robinette. 1994. Responses to hemorrhagic arterial pressure reduction in different ischemic renal failure models. Kidney Int. 46:318-323.

5. Witzgall, R., D. Brown, C. Schwarz, and J.V. Bonventre. 1994. Localization of proliferating cell number antigen, vimentin, c-Fos and clusterin in the post ischemic kidney: evidence for a heterogenous genetic response among nephron segments, and a large pool of mitotically active and differentiated cells. J. Clin. Invest. 93:2175-2188.

6. Brady, H.R., and G.G. Singer. 1995. Acute renal failure. Lancet. 346: 1533-1540.

7. Racusen, L.C. 1997. Pathology of acute renal failure structure/function correlations. Adv. Ren. Replace. Ther. 4:3-16.

8. Racusen, L.C., B.A. Fivush, Y.-L. Li, I. Slatnick, and K. Solez. 1991. Dissociation of tubular cell detachment and tubular cell death in clinical and experimental "acute tubular necrosis". Lab. Invest. 64:546-556.
9. Humes, H.D. 1995. Acute renal failure: prevailing challenges and prospects for the future. Kidney Int. 48:26-32.

10. Springer, T.A. 1994. Traffic signals for lymphocyte recirculation and leukocyte emigration: the multiple paradigm. Cell. 76:301-314.

11. Klausner, J.M., F.S. Paterson, G. Goldman, L. Kobzik, C. Rodzen, R. Lawrence, C.R. Valeri, D. Shapiro, and H.B. Hechtman. 1989. Postischemic renal injury is mediated by neutrophils and leukotrienes. Am. J. Physiol. 256: F794-F802.

12. Goligorsky, M.S., W. Lieberthal, L. Racusen, and E.E. Simon. 1993. Integrin receptors in renal tubular epithelium: new insights into pathophysiology of acute renal failure. Am. J. Physiol. 264:F1-F8.

13. Kelly, K.J., W.W. Williams, Jr., R.B. Colvin, and J.V. Bonventre. 1994. Intercellular adhesion molecule 1 protects the kidney against ischemic injury. Proc. Natl. Acad. Sci. USA. 91:812-816.

14. Conger, J. 1997. Hemodynamic factors in acute renal failure. Adv. Ren. Replace. Ther. 4:25-37.

15. Humes, H.D., and S. Liu. 1994. Cellular and molecular basis of renal repair in acute renal failure. J. Lab. Clin. Med. 124:749-754.

16. Hammerman, M.R., and S.B. Miller. 1994. Therapeutic use of growth factors in renal failure. J. Am. Soc. Nephrol. 5:1-11.

17. Harris, R.C. 1997. Growth factors and cytokines in acute renal failure. Adv. Ren. Replace. Ther. 4:43-53.

18. Humes, H.D., D.A. Cieslinski, T. Coimbra, J.M. Messana, and C. Galvao. 1989. Epidermal growth factor enhances renal tubule cell regeneration and repair and accelerates the recovery of renal function in postischemic acute renal failure. J. Clin. Invest. 84:1757-1761.

19. Miller, S.B., D.R. Martin, J. Kissane, and M.R. Hammerman. 1994. Insulin-like growth factor I accelerates recovery from ischemia acute tubular necrosis in the rat. Proc. Natl. Acad. Sci. USA. 89:11876-11880.

20. Miller, S.B., D.R. Martin, J. Kissane, and M.R. Hammerman. 1994. Hepatocyte growth factor accelerates recovery from acute ischemic renal injury in rats. Am. J. Physiol. 266:129-134.

21. Urist, M.R. 1965. Bone: formation by autoinduction. Science. 150:893-899.

22. Sampath, T.K., and A.H. Reddi. 1981. Dissociative extraction and reconstitution of extracellular matrix components involved in local bone differentiation. Proc. Natl. Acad. Sci. USA. 78:7599-7602.

23. Hogan, B.L.M. 1996. Bone morphogenetic proteins in development. Curr. Opin. Genet. Dev. 6:432-438.

24. Helder, M.N., E. Ozkaynak, T.K. Sampath, F.P. Luyten, V. Latin, H. Oppermann, and S. Vukicevic. 1995. Expression pattern of osteogenic protein-1 (bone morphogenetic protein-7) in human and mouse development. J. Histochem. Cytochem. 43:1035-1043.

25. Vukicevic, S., J.B. Kopp, F.P. Luyten, and T.K. Sampath. 1996. Induction of nephrogenic mesenchyme by osteogenic protein 1 (bone morphogenetic protein-7). Proc. Natl. Acad. Sci. USA. 93:9021-9026.

26. Dudley, A.T., K.M. Lyons, and E.J. Robertson. 1995. A requirement for bone morphogenetic protein-7 during development of the mammalian kidney and eye. Genes Dev. 9:2795-2807.

27. Luo, G., C. Hofmann, A.L.J.J. Bronckers, M. Sohocki, A. Bradley, and G. Karsenty. 1995. BMP-7 is an inducer of nephrogenesis, and is also required for eye development and skeletal patterning. Genes Dev. 9:2808-2820.

28. Ozkaynak, E., P.N.J. Schnegelsberg, and H. Oppermann. 1991. Murine osteogenic protein-1 (OP-1): high levels of mRNA in kidney. Biochem. Biophys. Res. Commun. 179:116-123.

29. Sampath, T.K., J.C. Maliakal, P.V. Hauschka, W.K. Jones, H. Sasak, R.F. Tucker, K.H. White, J.E. Coughlin, M.M. Tucker, R.H.L. Pang, et al. 1992. Recombinant human osteogenic protein-1 (hOP-1) induces new bone formation in vivo with a specific activity comparable with natural bovine osteogenic protein and stimulates osteoblast proliferation and differentiation in vitro. $J$. Biol. Chem. 267:20352-20262.

30. Vukicevic, S., V. Latin, P. Chen, R. Batorsky, A.H. Reddi, and T.K Sampath. 1994. Localization of osteogenic protein-1 (bone morphogenetic protein-7) during human embryonic development: high affinity to basement membranes. Biochem. Biophys. Res. Commun. 198:693-700.

31. Bosukonda, D., A. Schneyer, and R.E. Reicher. 1986. Solubilization of functional and stable follitropin receptors from light membranes of bovine calf testis. J. Biol. Chem. 261:13104-13113.

32. Vukicevic, S., A. Stavljenic, T. Boll, M. Cervar, C. Degenhardt, T. Mihaljevic, and B. Krempien. 1989. The influence of early parathyroidectomy on aluminum-induced rickets in growing uremic rats. Bone Miner. 6:125-139.

33. Whelton, A.W., A.J. Watson, and R.C. Rock. 1994. Nitrogen metabolites and renal function. In Clinical Chemistry. C.A. Burtis and E.R. Ashwood, editors. W.B. Saunders, Philadelphia, PA. 1513-1575.

34. Seiberg, M., S. Wisniewski, G. Canwenbergh, and S.S. Shapiro. 1997. Trypsin-induced follicular papilla apoptosis results in delayed hairgrowth and pigmentation. Dev. Dyn. 208:553-564.

35. Shepard, A., J. Maliakal, H. Dorai, D. Jin, N. Basic, H. Opperman, S. Vukicevic, and T.K. Sampath. 1997. OP-1 suppresses ICAM expression in an ARF model as well as in cultured renal cells. J. Am. Soc. Nephrol. 8:2257A.

36. Matejka, G.L., and E. Jennische. 1992 IGF-I binding and IGF-I mRNA expression in the post-ischemic regenerating rat kidney. Kidney Int. 42:11131123 . 
37. Price, P.M., J. Megyesi, S. Saggi, and R.L. Safirstein. 1995. Regulation of transcription by the rat EGF gene promoter in normal and ischemic murine kidney cells. Am. J. Physiol. 268:F664-F670.

38. Lefer, A.M., P.S. Tsao, X.L. Ma, and T.K. Sampath. 1992. Anti-ischemic and endothelial protective actions of recombinant human osteogenic protein-1. J. Mol. Cell. Cardiol. 24:585-593.

39. Perides, G., F.E. Jensen, P. Edgecomb, D.C. Rueger, and M.E. Charness. 1995. Neuroprotective effect of human osteogenic protein-1 in a rat model of cereberal hypoxia/ischemia. Neurosci. Lett. 187:21-24.

40. Chiao, H., Y. Kohda, P. McLeroy, L. Craig, I. Housini, and R. Star.
1997. $\alpha$-Melanocyte-stimulating hormone protects against renal injury after ischemia in mice and rats. J. Clin. Invest. 99:1165-1172.

41. Chan, T., S. Falk, and J. Conger. 1997. Effect of osteogenic protein-1 on the course of norepinephrine-induced acute renal failure. J. Am. Soc. Nephrol. 8:2721A.

42. Dorai, H., A. Shepard, J. Maliakal, H. Oppermann, S. Vukicevic, and T.K. Sampath. 1997. Osteogenic protein-1 (OP-1/BMP-7) modulates smooth muscle cell growth and maintains the expression of cell phenotype and protects against cell injury mediated by nephrotoxic and inflammatory agents in vitro. $J$. Am. Soc. Nephrol. 8:1366A. 